\title{
JOLANTA KUROSZ \\ Materiały do ćwiczeń z teologii pastoralnej szczegółowej oraz teologii laikatu i apostolstwa. Wskazówki metodyczne
}

Wydział Teologiczny Uniwersytetu im. Adam Mickiewicza w Poznaniu opublikował w 2012 r. książkę z serii pomocy naukowych, pt. Teologia pastoralna. Materiały do ćwiczeń. Część druga. Teologia pastoralna szczegółowa wybrane zagadnienia. Teologia laikatu $i$ apostolstwa. Publikacja, podobnie jak jej pierwsza część ${ }^{1}$ jest skierowana zarówno do prowadzących zajęcia ze wspomnianych przedmiotów oraz studentów. Jest ona uwieńczeniem poszukiwań skutecznego procesu dydaktycznego, który ma miejsce w ramach kształcenia pastoralnego na wyższych uczelniach w Polsce.

Niniejszy artykuł zamyka pierwszy w Polsce cykl publikacji, w którym autorka podjęła próbę kompleksowego zaprezentowania tematyki dotyczącej ćwiczeń z teologii pastoralnej, tzn. od ukazania znaczenia tychże zajęć w kształceniu uniwersyteckim wraz z próbą umiejscowienia ich w kształceniu pastoralnym ${ }^{2}$, poprzez materiały do ćwiczeń dla studentów i wykładowców (dwie części), do przekazania wskazówek metodycznych, skierowanych do prowadzących zajęcia.

Jolanta K U R O S Z, dr, adiunkt w Zakładzie Teologii Pastoralnej, Wydział Teologiczny Uniwersytetu im. Adama Mickiewicza w Poznaniu, e-mail: kurosz@amu.edu.pl

${ }^{1}$ J. K u r o s z: Teologia pastoralna. Materialy do ćwiczeń. Część pierwsza. Teologia pastoralna fundamentalna. Poznań 2009 . Wskazówki metodyczne zostały zaprezentowane w artykule pt.: Materialy do ćwiczeń z teologii pastoralnej fundamentalnej. Wskazówki metodyczne. „Teologia Praktyczna". T. 11: 2010 s. 259-285.

${ }^{2}$ Por. J. K u ro s z: Ćwiczenia z teologii pastoralnej dla studentów uniwersyteckich wydziatów teologicznych. „Teologia Praktyczna”. T. 4: 2003 s. 343-360. 
Teksty oraz polecenia zawarte $\mathrm{w}$ prezentowej publikacji nie wyczerpują całości zagadnienia tematyki ćwiczeń z tychże przedmiotów. W 2002 r. ukazał się podręcznik pod redakcją ks. prof. Ryszarda Kamińskiego pt. Teologia pastoralna. Tom 2. Teologia pastoralna szczegółowa. Zawiera on wiele cennych zagadnień, które mogą i powinny być wykorzystane podczas ćwiczeń, dlatego też niektóre tematy zostały celowo pominięte $\mathrm{w}$ drugiej części książki - dotyczy to w szczególny sposób teologii pastoralnej szczegółowej. Wszystkie wspomniane publikacje mogą stanowić inspirację do przygotowania zajęć dydaktycznych w ramach kształcenia pastoralnego.

W opracowaniu przypomniano cele ogólne ćwiczeń teologii pastoralnej oraz przedstawiono cele i efekty kształcenia realizowane podczas ćwiczeń z teologii pastoralnej szczegółowej oraz teologii laikatu i apostolstwa. Ponadto podano wskazówki metodyczne, które mogą być przydatne podczas prowadzania wspomnianych zajęć dydaktycznych. Celem niniejszego artykułu była próba stworzenia pomocy naukowej dla prowadzących zajęcia. Układ treści prezentowanej publikacji jest podobny do artykułu, który ukazał się w „Teologii Praktycznej” w $2010 \mathrm{roku}^{3}$. Wiele wskazówek, które zostały przedstawione w artykule w 2010 r., mimo iż zostały pominięte $\mathrm{w}$ niniejszym opracowaniu, nadal są aktualne $\mathrm{i}$ mogą służyć pomocą osobom prowadzącym zajęcia ${ }^{4}$.

\section{Cele i efekty kształcenia w ramach ćwiczeń $\mathrm{z}$ teologii pastoralnej szczegółowej}

Celem ćwiczeń z teologii pastoralnej jest rozwijanie umiejętności posługiwania się zdobytą wiedzą, dotyczącą codziennego wzrastania Kościoła w mocy Ducha Świętego w kontekście historii. Odbywa się to przy pomocy tzw. celów pośrednich, tj.: kształtowania umiejętności rozeznawania sytuacji społecznokulturowej i kościelnej, w której prowadzona jest działalność duszpasterska Kościoła, analizie zasad i kryteriów działalności duszpasterskiej Kościoła, analizie i pogłębieniu znajomości dokumentów Kościoła pod kątem pastoralnym, rozwijania umiejętności posługiwania się zdobytą wiedzą z zakresu teologii pastoralnej w celu opracowania poszczególnych problemów, kształtowania umiejętności formułowania duszpasterskich wniosków i postulatów oraz całościowego spojrzenia na Kościół jako komunię

\footnotetext{
${ }^{3}$ Por. J. K u r o s z: Materiały do ćwiczeń z teologii pastoralnej fundamentalnej ..., dz. cyt., s. $260-285$

${ }^{4} \mathrm{~W}$ artykule wskazano także miejsca, gdzie zauważono błędy redakcyjne, pomimo dokonania licznych korekt przed ukazaniem się podręcznika.

${ }^{5}$ Por. J. K u r o s z: Ćwiczenia z teologii pastoralnej dla studentów ..., dz. cyt., s. 349-350.
} 
Cele wraz zakładanymi efektami kształcenia, które powinien osiągnąć student uczestniczący w ćwiczeniach z teologii pastoralnej szczegółowej nie mogą być sprzeczne z wyżej wymienionymi celami. W prezentowanych materiałach do ćwiczeń określono następujące cele dydaktyczne: przekazanie wiedzy o podstawowych wymogach działalności duszpasterskiej w poszczególnych jej obszarach oraz o podstawowych miejscach realizacji działalności duszpasterskiej Kościoła; rozwinięcie umiejętności zastosowania metody badań teologii pastoralnej $\mathrm{w}$ analizie duszpasterskiej oraz prowadzenia pogłębionej refleksji związanej z działalnością Kościoła w oparciu o teologiczne zasady duszpasterstwa; kształcenie podstawowych kompetencji duszpasterskich; rozwinięcie umiejętności komunikacji i pracy zespołowej.

Konsekwencją tak sformułowanych celów powinny być efekty kształcenia $\mathrm{w}$ trzech płaszczyznach, $\mathrm{tj}$.

- wiedzy: student powinien znać źródła i zasady kryteriów działalności duszpasterskiej oraz wymienić podstawowe miejsca realizacji duszpasterstwa, także dokonać wyjaśnić ich specyfikę,

- umiejętności: student powinien stosować metodę analizy pastoralnej w odniesieniu do poszczególnych obszarów działalności duszpasterskiej oraz ocenić konkretną sytuację duszpasterską w świetle jej zasad i kryteriów,

- kompetencji: student powinien znać i kształtować w sobie podstawowe kompetencje duszpasterskie, posiadać zdolność do wykorzystania zasad kierowania zespołem oraz być otwartym na prowadzenie wspólnie z innymi badań z zakresu teologii pastoralnej.

W zależności od grupy studentów uczestniczących w zajęciach, np. klerycy lub studenci świeccy, wyżej wymienione cele i efekty kształcenia powinny być nieznacznie zmodyfikowane.

\section{Wskazówki metodyczne}

\section{ROZDZIAŁ I: Duszpasterstwo w misji Kościoła}

CEL OGÓLNY: przekazanie wiedzy o podstawowych wymogach i miejscach działalności duszpasterskiej w poszczególnych jej obszarach, rozwinięcie umiejętności prowadzania pogłębionej refleksji związanej z działalnością Kościoła w oparciu o teologiczne zasady duszpasterstwa. 


\section{Rodzaje duszpasterstwa}

POLECENIE 1 s. 16: a) Przypomnij sobie definicję duszpasterstwa ${ }^{6}$. b) Przypomnij sobie podstawy teologii pastoralnej ${ }^{7}$. c) Uzasadnij, dlaczego duszpasterstwo jest podstawową formą nowej ewangelizacji.

Cel - uporządkowanie i powtórzenie podstawowych wiadomości dotyczących duszpasterstwa zawartych dokumentach Kościoła.

Wskazówka metodyczna - poza proponowanym Dyrektorium ogólnym o katechizacji, można polecić studentom powtórzenie wiadomości dotyczących podstaw działalności duszpasterskiej Kościoła, które zostały zawarte w 1 części Materiałów do ćwiczeń s. 22-23 i 117-161.

POLECENIE 2 s. 21: a) Przedstaw duszpasterstwo zwyczajne i nadzwyczajne Kościoła. b) Narysuj schemat przedstawiający duszpasterstwo Kościoła (rodzaje, cele duszpasterstwa grupy osób do których jest kierowana dzielność zbawcza). c) Wybierz jeden przejaw duszpasterstwa zwyczajnego w parafii Twojego pochodzenia. Dokonaj szczegółowej charakterystyki. d) Wybierz jeden przejaw duszpasterstwa nadzwyczajnego. Dokonaj szczegółowej charakterystyki.

Cel - student powinien wskazać rodzaje i cele duszpasterstwa oraz przedstawić ich charakterystykę, posiadać umiejętność analizy duszpasterskiego oddziaływania, uwzględniając powyższy podział.

POLECENIE 3 s. 23: a) Wymień przejawy duszpasterstwa zwyczajnego i nadzwyczajnego zaprezentowane $w$ tekście. b) $\mathrm{Z}$ jakimi trudnościami spotykają się duszpasterze $\mathrm{w}$ obecnym czasie $\mathrm{w}$ ramach działalności duszpasterskiej? Wskaż źródło tychże problemów. c) Wykorzystując wiedzę z zakresu teologii pastoralnej oraz znajomość dokumentów Kościoła zaproponuj rozwiązanie wskazanych zagadnień (patrz: podpunkt a) nastręczających trudności w działalności duszpasterskiej.

Cel - student powinien znać podstawowe miejsca realizacji duszpasterstwa oraz wyjaśnić ich specyfikę; kształcenie umiejętności pogłębionej analizy duszpasterskiej rzeczywistości oraz rozwijanie umiejętności komunikacji i pracy zespołowej.

${ }^{6}$ Por. J. Ku ros z: Teologia pastoralna. Materiaty do ćwiczeń. Część pierwsza..., dz. cyt., s. 22-23.

Wiadomości można uzyskać m.in.: Teologia pastoralna. T. 1. Teologia pastoralna fundamentalna. Red. R. K a m i ń s k i. Lublin 2000; Teologia pastoralna. Materiaty do ćwiczeń. Część pierwsza. Teologia pastoralna fundamentalna. Red. J. K u r o s z. Poznań 2009 s. 117-164. 
Wskazówka metodyczna - studenci w zespołach 2-3 osobowy przygotowują odpowiedzi (podpunkt b i c), prezentacje można przeprowadzić na wzór debaty.

POLECENIE 4 s. 26: a) Wskaż przejawy duszpasterstwa zwyczajnego w parafii Twojego pochodzenia. b) Wybierz jeden przejaw duszpasterstwa zwyczajnego (patrz: podpunkt a). Oceń jego realizację uwzględniając zasadę personalistyczno-chrystologiczną i eklezjologiczną duszpasterstwa ${ }^{8}$. c) Wskaż przejawy duszpasterstwa nadzwyczajnego w Twojej diecezji. Wybierz jeden i oceń jego realizację uwzględniając zasadę personalistyczno-chrystologiczną i eklezjologiczną duszpasterstwa9. d) Które z przedstawionych w tekście wniosków i wskazań pastoralnych są nadal aktualne. Uzasadnij swoją odpowiedź.

Cel - utrwalenie wiadomości z zakresu prezentowanego materiału, kształcenie umiejętności pogłębionej analizy duszpasterskiej rzeczywistości oraz rozwijanie umiejętności komunikacji i pracy zespołowej.

Wskazówka metodyczna - patrz: POLECENIE 3 s. $23^{10}$.

\section{Duszpasterstwo działalnością zorganizowaną}

POLECENIE 1 s. 28: a) Wymień urzędy Kurii Rzymskiej oraz wskaż ich główne zadania. Poszukaj, np. w „L’Osservatore Romano” dokumentów Kościoła ogłoszonych przez urzędy watykańskie. Zaprezentuj tematykę wybranego przez siebie dokumentu, który jest związany z działalnością duszpasterską Kościoła.

Cel - student powinien wymienić urzędy Kurii Rzymskiej oraz krótko scharakteryzować ich działalność, kształcenie umiejętności analizy dokumentów Kościoła.

Wskazówka metodyczna - praca pisemna studenta wykonana przed zajęciami.

POLECENIE 2 s. 31: a) Wymień struktury diecezjalne Kościoła. Wybierz jedną i przedstaw jej działania. b) Przedstaw działalność Kościoła na poziomie diecezjalnym wykorzystując najnowsze dokumenty synodalne Twojej diecezji.

${ }^{8}$ Por. J. K u r o s z: Teologia pastoralna. Materiaty do ćwiczeń. Część pierwsza ..., dz. cyt., s. $122-128$

${ }^{9}$ Por. tamże.

${ }^{10} \mathrm{~W}$ artykule podano strony z podręcznika, na których umieszczono polecenia dla studentów. 
Cel - student powinien wymienić struktury diecezjalne Kościoła oraz przedstawić ich działalność; kształcenie umiejętności analizy dokumentów Kościoła pod kątem wybranego zagadnienia.

Wskazówka metodyczna - patrz: POLECENIE 1 s. 28.

POLECENIE 3 s. 33: a) Przedstaw działalność laikatu i duchowieństwa w wybranych przez siebie strukturach w diecezji.

Cel - praktyczne zastosowanie wiadomości z zakresu duszpasterstwa, jako działalności zorganizowanej; kształcenie umiejętności interpretowania i wyjaśniania relacji, jakie zachodzą w działalności duszpasterskiej, między laikatem i duchowieństwem.

Wskazówka metodyczna - powyższe zadanie może być potraktowanie jako wprowadzenie do tematyki rozdziału V: Prezbiterzy i świeccy we wspólnocie Kościoła, s. 315.

POLECENIE 4 s. 35: a) Zapoznaj się z dokumentami Kościoła, wymienionymi w tekście, tj.: Dekret o pasterskich zadaniach biskupów w Kościele Christus Dominus, pkt 27-28; Dekret o posłudze i życiu kapłanów Presbyterorum ordinis, pkt 7; Kodeks Prawa Kanonicznego (kanony i paragrafy wymienione w tekście). b) Przedstaw nauczanie Kościoła dotyczące rad działających przy biskupie. c) Na podstawie dostępnych informacji, przeprowadzonych wywiadów opisz działalność rad działających przy biskupie w Twojej diecezji.

Cel - analiza dokumentów Kościoła ukazujących rady działające przy biskupie; kształcenie umiejętności przeprowadzenia analizy działalności duszpasterskiej Kościoła, formułowania wniosków oraz posługiwania się zdobytą wiedzą zakresu prezentowanego tematu.

POLECENIE 5 s. 37: a) Wymień zadania dziekana. W odpowiedzi uwzględnij Kodeks Prawa Kanonicznego, zwłaszcza kanony 553-555. b) Odpowiedz, w jaki sposób powyższe zadania są realizowane w dekanacie, do którego przynależy Twoja wspólnota parafialna.

Cel - pogłębienie znajomości Kodeksu Prawa Kanoniczego w zakresie obowiązków dziekana, kształcenie umiejętności praktycznego wykorzystania zdobytej wiedzy, analizy działalności duszpasterskiej Kościoła na poziomie dekanatu, formułowania wniosków duszpasterskich oraz umiejętności komunikacji i pracy zespołowej. 
Wskazówka metodyczna - praca w zespołach kilkuosobowych, wskazane przeprowadzenie wywiadu z księdzem dziekanem, wikariuszami oraz innymi członkami poszczególnych parafii tworzących dekanat.

POLECENIE 6 s. 43: a) Zapoznaj się dokumentami Kościoła: Jan Paweł II: Adhortacja apostolska Christifideles laici, pkt 26; Kodeks Prawa Kanonicznego kan. $515 \S 1,519,521$; Sobór Watykański II: Dekret o pasterskich zadaniach biskupów Christus Dominus, pkt 30. b) Wymień zadania, które przynależą do urzędu proboszcza. W odpowiedzi uwzględnij najnowsze dokumenty synodalne Twojej diecezji.

Cel - zapoznanie i pogłębienie znajomości treści dokumentów Kościoła, ukazujących zadania proboszcza; kształcenie umiejętności analizy dokumentów Kościoła pod kątem wybranego zagadnienia.

\section{Duszpasterstwo działalnością planowaną}

POLECENIE 1 s. 46: a) Zapoznaj się z dokumentem Kościoła: Sobór Watykański II: Konstytucja duszpasterska o Kościele w świecie współczesnym $G a$ dium et spes, pkt 3-4; Jan Paweł II: List apostolski Novo millennio ineunte, rozdz. 3. b) Zapoznaj się z programem duszpasterskim obowiązującym w bieżącym roku kościelnym. Poszukaj w nim propozycji duszpasterskich, o których wspomina Jan Paweł II w swoim liście. c) Odpowiedz, w jaki sposób owe propozycje są realizowane w parafii.

Cel - zapoznanie i pogłębienie znajomości treści dokumentów Kościoła ukazujących sytuację człowieka we współczesnym świecie oraz zadania duszpasterskie Kościoła we współczesnym świecie; kształcenie umiejętności praktycznego zastosowana zdobytej wiedzy, krytycznej oceny działalności duszpasterskiej, formułowania duszpasterskich wniosków i postulatów.

POLECENIE 2 s. 50: a) Scharakteryzuj dwa sposoby planowania duszpasterskiego. b) Uzupełnij swoją wypowiedź o treści zawarte w tekście nr $1 \mathrm{~s} .318-$ $322 \mathrm{w}$ pierwszej części tego podręcznika ${ }^{11}$. c) Odpowiedz, w jaki sposób realizowany jest program duszpasterski w Twojej parafii? d) Oceń sposób zaangażowania wiernych $\mathrm{w}$ Twojej parafii w realizację programu duszpasterskiego.

Cel - student powinien wymienić i scharakteryzować sposoby planowania duszpasterskiego; kształcenie umiejętności praktycznego zastosowania zdobytej wiedzy w ocenie realizacji programów duszpasterskich w parafii, formułowania

${ }^{11}$ Por. J. K u ro s z: Teologia pastoralna. Materiaty do ćwiczeń. Część pierwsza. Teologia pastoralna fundamentalna. Poznań 2009 s. 318-332. 
wniosków i postulatów, komunikacji oraz rozwijania podstawowych kompetencji duszpasterskich.

Wskazówka metodyczna - studenci powinni zapoznać się także z tekstem nr 1, podrozdziału: Realizacja programów duszpasterskich, s. 51-54.

Propozycja: jedna grupa przygotowuje materiał na zajęcia i przedstawia przygotowaną prezentację (nauczanie Kościoła, główne założenia programu duszpasterskiego oraz sposób jego realizacji), pozostali uczestnicy notują spostrzeżenia, po czym następuje dyskusja i próba sformułowania wniosków i postulatów.

POLECENIE 3 s. 54: a) Zapoznaj się z planem duszpasterskim o którego realizacji wspomina abp Stanisław Gądecki, K. Kantowski, W. Przygoda, S. Stułkowski: Szczegółowy program duszpasterski na rok 2007/2008. Bądźmy uczniami Chrystusa. W: Komisja Duszpasterstwa Episkopatu Polski: Kościół niosacy Ewangelię nadziei. Program duszpasterski Kościoła w Polsce na lata 20062010. Bądźmy uczniami Chrystusa. Poznań 2007 s. 13-28. b) Przedstaw szczegółowo osiem sposobów realizacji powyższego programu duszpasterskiego. c) Zapoznaj się z aktualnym planem duszpasterskim. Przedstaw w jaki sposób jest on realizowany w Twojej parafii.

Cel - student powinien znać sposoby realizowania programów duszpasterskich; kształcenie umiejętności praktycznego zastosowania zdobytej wiedzy oraz podstawowych kompetencji duszpasterskich.

Wskazówka metodyczna - praca pisemna studenta wykonana przed zajęciami; inna możliwość: studenci w zespołach 2-3 osobowy przygotowują prezentację, którą można przeprowadzić na wzór debaty.

UWAGA - studenci powinni wykorzystać w opracowaniu zdobytą wiedzą z zakresu urzeczywistnia się Kościoła w liturgii, martyrii i diakonii oraz kariologii ${ }^{12}$.

POLECENIE 4 s. 58: a) Zapoznaj się z aktualnym programem duszpasterskim. b) Wybierz jedną propozycję z programu i przygotuj projekt pastoralny, który może być zrealizowany w Twojej parafii. Uwzględnij uwarunkowania wspólnoty parafialnej. Wykorzystaj treści zawarte w rozdziale Podstawy pasto-

${ }^{12}$ Wiadomości znajdują się m.in. w podręczniku pod redakcją ks. prof. R. K a m i ń s k i e g o pt. Teologia pastoralna. Tom 1. Teologia pastoralna fundamentalna oraz w pierwszej części materiałów do ćwiczeń: J. K u ro s z: Teologia pastoralna. Materiaty do ćwiczeń. Część pierwsza..., dz. cyt., s. $165-318$. 
ralno-organizacyjne wieloletniego programu duszpasterskiego $\mathrm{w}$ pierwszej części tego podręcznika ${ }^{13}$.

Cel - student powinien wykazać się znajomością aktualnie obowiązującego programu duszpasterskiego; kształcenie umiejętności: praktycznego zastosowania zdobytej wiedzy w zakresie planowania i programowania duszpasterskiego, krytycznej oceny działalności duszpasterskiej, formułowania duszpasterskich wniosków i postulatów.

\section{Duszpasterstwo działalnością zespołową}

UWAGA: Dla studentów, którzy nie mają ćwiczeń z teologii laikatu i apostolstwa $\mathrm{w}$ ramach kształcenia pastoralnego, proponuję przy omawianiu tego zagadnienia wykorzystać treści wraz z poleceniami z części II, tj. Teologii laikatu i apostolstwa, s. 251-331.

POLECENIE 1 s. 61: a) Zapoznaj się z treścią Konstytucji dogmatycznej o Kościele Lumen gentium rozdz. 3-4, 6. b) Przedstaw zadania poszczególnych członków Kościoła w jego misji kapłańskiej, prorockiej i królewskiej. c) Odpowiedz na pytanie, dlaczego nie wszyscy wierni identyfikuja się w petni $i$ catkowicie z Kościolem i jego pierwszoplanowym posłannictwem? Jakie widzisz rozwiązanie dla zaistniałej sytuacji?

Cel - przypomnienie i pogłębienie znajomości Konstytucji dogmatycznej o Kościele Lumen gentium, ukazujące Kościół jako wspólnotę Ludu Bożego; kształcenie umiejętności praktycznego zastosowania nauczania Kościoła w analizie rzeczywistości pastoralnej oraz formułowanie wniosków i postulatów.

Wskazówka metodyczna - tutaj można wykorzystać materiał z części drugiej podręcznika, podrozdział: Świeccy we wspólnocie Ludu Bożego po Soborze Watykańskim II, POLECENIE 3 s. 280.

POLECENIE 2 s. 65: a) Zapoznaj się treścią Kodeksu Prawa Kanonicznego, kan. 225-227. b) Uwzględniając treści zawarte w powyższych tekstach opisz idealną współpracę duszpasterzy i laikatu w działalności pastoralnej Kościoła. c) Przedstaw współpracę duchowieństwa i laikatu w wspólnocie parafialnej, organizacji katolickiej lub stowarzyszeniu. d) Porównaj idealną współpracę (patrz podpunkt a) z rzeczywistością. Wskaż możliwości usprawnienia działania duchowieństwa i laikatu.

${ }^{13}$ Por. J. K u ro s z: Teologia pastoralna. Materiaty do ćwiczeń. Część pierwsza. Teologia pastoralna fundamentalna. Poznań 2009 s. 318-332. 
Cel - student powinien znać wskazania Kościoła dotyczących obowiązków i praw wiernych świeckich; kształcenie umiejętności krytycznej oceny działalności duszpasterskiej w świetle poznanych dokumentów.

Wskazówka metodyczna - można wykorzystać teksty wraz z poleceniami z rozdziału Prezbiterzy i świeccy we wspólnocie Kościoła, s. 315-331, np. POLECENIE 1 s. 316.

POLECENIE 3 s. 67: a) Zapoznaj się dokumentami ostatniego synodu, który odbył się w Twojej diecezji. b) Przedstaw wskazania i wnioski duszpasterskie, które zostały podjęte podczas synodu diecezjalnego. Oceń stopień ich realizacji na płaszczyźnie diecezjalnej bądź parafialnej.

Cel - analiza dokumentów Kościoła pod kątem wybranego przez studenta zagadnienia; kształcenie umiejętności praktycznego zastosowania nauczania Kościoła w analizie rzeczywistości pastoralnej; formułowanie wniosków i postulatów pracy zespołowej oraz komunikacji.

Wskazówka metodyczna - poszczególne zespoły przygotowują wnioski i wskazania dla wybranych przez siebie wcześniej zagadnień.

POLECENIE 4 s. 68: a) Stwórz projekt pracy duszpasterskiej, którego celem będzie kształtowanie postawy współodpowiedzialności wiernych za życie parafii (lub wspólnoty). Uwzględnij aktualnie obowiązujący program duszpasterski. b) Przedstaw współpracę duchowieństwa i zakonników (zakonnic) w parafii lub diecezji. Jakie widzisz możliwości poszerzenia wspólnej pracy oraz możliwości rozwiązania obecnych trudności. c) Zaprezentuj współpracę duchowieństwa i świeckich w znanej Tobie parafii lub podczas wspólnego dzieła ponadparafialnego. Jakie widzisz możliwości poszerzenia wspólnej pracy oraz możliwości rozwiązania obecnych trudności.

Cel - kształcenie umiejętności: krytycznej oceny organizacji duszpasterstwa, wykorzystania tej wiedzy w tworzeniu projektów duszpasterskich, formułowania wniosków i postulatów oraz kształcenie podstawowych kompetencji duszpasterskich.

Wskazówka metodyczna - można wykorzystać teksty wraz z poleceniami z rozdziału Prezbiterzy i świeccy we wspólnocie Kościoła, s. 315-331, zwłaszcza POLECENIE 4 s. 328.

POLECENIE 5 s. 70: a) Odpowiedz, w jaki sposób członkowie parafii są zaangażowani w sprawowanie Eucharystii. Jakie widzisz możliwości większego zaangażowania pod tym względem. b) Napisz w jaki sposób jest realizowana 
współpraca między prezbiterami a członkami wspólnoty parafialnej lub w innych przejawach życia Kościoła.

Cel - utrwalenie wiedzy o duszpasterstwie, jako działalności zorganizowanej, kształcenie umiejętności praktycznego zastosowania wiedzy w zakresie omawianego zagadnienia, krytycznej oceny rzeczywistości znanej rzeczywistości parafialnej oraz kształcenie podstawowych kompetencji duszpasterskich.

POLECENIE 6 s. 74: a) Opisz inne formy wspólnej pracy członków Kościoła podejmowane zarówno w wymiarze duchowym, jak i praktycznym.

Cel - student powinien wymienić różne formy wspólnej pracy członków Kościoła; kształcenie umiejętności analizy wspomnianych przejawów, formułowania wniosków i postulatów oraz kształcenie podstawowych kompetencji duszpasterskich.

\section{Pastoralna tożsamość prezbitera}

POLECENIE 1 s. 76: a) Zapoznaj się z 3 rozdz. Adhortacji Jana Pawła II Pastores dabo vobis. Przedstaw charakterystykę życia duchowego prezbitera. b) Przedstaw cechy prezbitera niezbędne do owocnego posługiwania wśród wiernych. c) W jaki sposób słowa Jana Pawła II - starajcie się być ,,artystami”, odnoszą się zaangażowania prezbiterów w pracy duszpasterskiej. d) Jakie dostrzegasz przeszkody w wypełnieniu wskazań Papieża przez duchowieństwo.

Cel - zapoznanie lub pogłębienie znajomości dokumentów Kościoła ukazujących cechy prezbitera, które są niezbędne w posługiwaniu wśród wiernych; kształcenie umiejętności prowadzenia pogłębionej refleksji związanej z posługiwaniem prezbiterów oraz podstawowych kompetencji duszpasterskich.

POLECENIE 2 s. 79: a) Przedstaw konsekwencje dla posługi duszpasterskiej, jakie wynikają z prawdy ukazującej Kościół jako Ciało Chrystusa. b) Wymień niezbędne predyspozycje prezbitera, które są pomocne w budowaniu wspólnoty Kościoła.

Cel - rozwijanie umiejętności: pogłębionej refleksji nad działalnością zbawczą Kościoła, praktycznego wykorzystania zdobytej wiedzy w zakresie omawianego zagadnienia, formułowania wniosków i postulatów pastoralnych oraz podstawowych kompetencji duszpasterskich.

POLECENIE 3 s. 82: a) Czy prezbiterzy właściwie rozumieją i pełnią swą specyficzną funkcją duchowych przewodników wspólnot, które im zostały powierzone? Jak to czynią konkretnie? b) Jednym z głównych zadań duszpasterstwa jest zespalanie sił w służbie misji ewangelizacyjnej. Jak przyczyniamy się 
do budzenia wszelkich powołań we wspólnocie Kościoła i jak szanujemy charyzmaty wiernych?

Cel - analiza dokumentu Kościoła, ukazującego zadania prezbiterów, kształcenie umiejętności pogłębionej analizy duszpasterskiej rzeczywistości oraz formułowania wniosków i postulatów.

POLECENIE 4 s. 86: a) Przeprowadź wywiad z duszpasterzem akademickim o jego posłudze wśród studentów. Dowiedz się, w jaki sposób łączy on dwie przestrzenie tj. Kościoła i świata w środowisku akademickim? b) Przedstaw działalność ośrodka akademickiego ze szczególnym uwzględnieniem pracy duszpasterza. Wskaż jego kompetencje duszpasterskie pomocne w pracy.

$\mathrm{Cel}$ - student powinien przedstawić charakterystykę posługiwania prezbitera w duszpasterstwie akademickim; kształcenie umiejętności komunikacji.

\section{ROZDZIAL II: Duszpasterstwo zwyczajne Kościoła}

CEL OGÓLNY: przekazanie wiedzy o podstawowych wymaganiach duszpasterskiej działalności Kościoła, rozwinięcie umiejętności zastosowania metody badań teologii pastoralnej $\mathrm{w}$ analizie duszpasterskiej oraz komunikacji i pracy zespołowej.

\section{Teologiczna refleksja dotycząca parafii}

POLECENIE 1 s. 90: a) Napisz krótką charakterystykę parafii zawartą w dokumentach Kościoła. Pomocą mogą służyć następujące dokumenty: Jan Paweł II: Adhortacja apostolska Christifideles laici, pkt 25-27, 61; Katechizm Kościoła Katolickiego, pkt 2179, 2226; Dokumenty Soboru Watykańskiego II: Konstytucja dogmatyczna o Kościele Lumen gentium, pkt 26; Konstytucja o liturgii świętej Sacrosanctum Concilium, pkt 42; Dekert o pasterskich zadaniach biskupów w Kościele Christus Dominus, pkt 30-31; Dekret o apostolstwie świeckich Apostolicam actuositatem, 10, 30; Kodeks Prawa Kanonicznego, kan. 515-519, 528530; b) Wskaż konsekwencje dla posługi duszpasterskiej, wynikające z faktu, iż parafia jest wspólnotą zdolną do sprawowania Eucharystii (por. CHL 26).

Cel - student powinien znać nauczanie Kościoła o parafii jako wspólnocie Ludu Bożego; kształcenie umiejętności analizy dokumentów Kościoła oraz rozwinięcie pogłębionej refleksji związanej z działalnością Kościoła.

Wskazówka metodyczna - powyższe POLECENIE może stanowić wstęp do zagadnień związanych z parafią. 
POLECENIE 2 s. 94: a) Przedstaw poszczególne teorie teologiczne na temat parafii. b) Wskaż różnice i ewentualne podobieństwa w prezentowanych stanowiskach dotyczących parafii.

Cel - student powinien wymienić i przedstawić teorie naukowe na temat parafii; rozwijanie umiejętności prowadzenia pogłębionej refleksji związanej ze wspólnotą parafialną.

POLECENIE 3 s. 98: a) Przedstaw teologiczny aspekt parafii opracowany przez Hermana Wieha. Zapoznaj się z tekstami dokumentów Kościoła na które powołuje się teolog. Uwzględnij je w swojej prezentacji. b) Przedstaw teologiczny aspekt parafii opracowany przez Petera Byeng-Hun Lim oraz Ulricha Kuhnke.

Cel - student powinien znać teologiczny aspekt parafii opracowany przez w/w teologów.

POLECENIE 4 s. 104: a) Wskaż istotne więzi społeczności religijnej w ujęciu polskich socjologów. b) Wskaż istotne różnice między teologicznym i socjologicznym ujęciem parafii. c) Wykonaj tabelaryczne zestawienie najważniejszych treści dotyczących całej refleksji teologicznej na temat parafii.

$\mathrm{Cel}$ - student powinien wymienić więzi społeczności religijnej oraz wskazać różnice między teologicznym i socjologicznym ujęciem parafii; kształcenie podstawowych kompetencji duszpasterskich.

\section{Typologia parafii}

POLECENIE 1 s. 108: a) Wymień cechy charakterystyczne poszczególnych typów parafii. b) Dokonaj charakterystyki Twojej parafii. Porównaj jej cechy z wyżej wymienionymi typami.

Cel - student powinien dokonać charakterystyki poszczególnych typów parafii; kształcenie umiejętności wyszukiwania istotnych wiadomości dotyczących omawianego zagadnienia oraz praktycznego zastosowania zdobytej wiedzy.

POLECENIE 2 s. 110: a) Odpowiedz na pytanie zawarte na końcu powyższego tekstu, tj. Jakiego zatem dokonać wyboru, by parafia objawiała jak najpetniej zycie Kościoła? b) Wybierz jeden „typ” postrzegania parafii. Wykorzystując wiadomości z zakresu teologii pastoralnej ogólnej, spróbuj opracować główne wytyczne dla działalności duszpasterskiej, które mogłyby pomóc w postrzeganiu parafii jako wspólnoty. 
Cel - kształcenie praktycznego zastosowania zdobytej wiedzy, umiejętności formułowania wniosków i postulatów pastoralnych oraz umiejętności komunikacji i pracy zespołowej.

Wskazówka metodyczna - podpunkt a) może posłużyć jako zadania do wykonania podczas kolokwium, natomiast podpunkt b): zespoły 2-3 osobowe podczas ćwiczeń opracowują wytyczne, po czym wzajemnie wymieniają się swoją pracą i na forum grupy omawiają pracę innego zespołu.

UWAGA: o ile grupy ćwiczeniowe są liczne odpowiedzi na podpunkt b) zespoły opracowują przed zajęciami.

\section{Parafia miejscem duszpasterstwa zwyczajnego}

POLECENIE 1 s. 112: a) Wskaż, w jaki sposób są realizowane zadania, które wymienił Benedykt XVI w powyższym tekście, w Twojej parafii. b) Które z wymienionych przejawów życia parafii nastręczają najwięcej problemów. Co jest przyczyną tych trudności? Jakie widzisz możliwości rozwiązanie zaistniałej sytuacji. c) Dokonaj szczegółowego rozeznania dotyczącego działań podjętych w konkretnej parafii, które mają na celu budowanie parafii jako „wspólnoty kościelnej” i „kościelnej rodziny”.

Cel - kształcenie praktycznego wykorzystania zdobytej wiedzy, umiejętności prowadzenia pogłębionej refleksji nad działalnością Kościoła w oparciu o teologiczne zasady duszpasterstwa.

Wskazówka metodyczna - studenci powinni powtórzyć zasadę personalistyczną i eklezjologiczną teologii pastoralnej i duszpasterstwa przed wykonaniem zadania ${ }^{14}$.

POLECENIE 2 s. 115: a) Przedstaw oddziaływania pastoralne, w znanej Ci rzeczywistości pastoralnej, które przyczyniają się do doświadczania przez wiernych kościelnej komunii. b) Wskaż trudności jakie napotykają duszpasterze w budowaniu parafialnej wspólnoty. Jakie są ich przyczyny? Jakie widzisz możliwości przezwyciężenia tychże trudności. c) Przedstaw działalność parafialnej rady duszpasterskiej i ekonomicznej w Twojej parafii.

POLECENIE 3 s. 117: a) Wskaż konkretne przejawy życia parafii w ramach martyrii, liturgii i diakonii, które czynią z niej prawdziwą wspólnotę wierzących. b) Dokonaj analizy życia swojej parafii, w której uwzględnisz wyżej wymienionej przejawy.

\footnotetext{
${ }^{14}$ Por. tamże, s. $117-128$.
} 
Cel - rozwinięcie umiejętności: zastosowania metody badań teologii pastoralnej w analizie duszpasterskiej, pogłębieniowej refleksji związanej w działalnością Kościoła we wspólnocie parafialnej, praktycznego zastosowania zdobytej wiedzy, formułowania wniosków i postulatów pastoralnych.

Wskazówka metodyczna - przed wykonaniem zadania, studenci powinni powtórzyć materiał z zakresu metodologii nauk pastoralnych oraz urzeczywistniania się Kościoła jako wspólnoty Ludu Bożego w liturgii, martyrii i diakonii ${ }^{15}$.

POLECENIE 4 s. 120: a) Opisz wspólnotowe elementy Twojej parafii. b) Spróbuj sformułować rzeczywiste problemy duszpasterskie w Twojej parafii oraz wskaż możliwości ich rozwiązania. c) Jakie widzisz możliwości większego zaangażowania wiernych w życie wspólnoty?

Cel - student powinien posiąść zdolność opisywania wspólnotowych elementów parafii; kształcenie umiejętności praktycznego wykorzystania zdobytej wiedzy, formułowania wniosków i postulatów pastoralnych oraz kompetencji duszpasterskich.

Wskazówka metodyczna - patrz: POLECENIE 2 s. 115 i POLECENIE 3 s. 117.

POLECENIE 5 s. 124: a) Zapoznaj się dokumentami Kościoła: Jan Paweł II: Adhortacja apostolska Pastores dabo vobis. „L'Osservatore Romano”. Wydanie polskie. R. 13: 1992 nr 3-4 (141) s. 4-63 pkt 26-27; Sobór Watykański II: Dekret o ekumenizmie Unitatis redintegratio, pkt 5; Konstytucja dogmatyczna o Kościele Lumen gentium, pkt 28; b) Przedstaw zadania spoczywające na proboszczu. Wykorzystaj nauczanie Kościoła (podpunkt a).

Cel - student powinien zdobyć umiejętność dokonywania analizy dokumentów Kościoła ukazujących zadania proboszcza; kształcenie umiejętności opracowania zadanego tematu z zakresu teologii pastoralnej na podstawie wybranych dokumentów.

Wskazówka metodyczna - tematykę można poszerzyć o treści zawarte w podrozdziale: Prezbiterzy i świeccy we wspólnocie Kościoła, s. 313-331.

POLECENIE 6 s. 127: a) Zapoznaj się tekstami Soboru Watykańskiego II: Konstytucja dogmatyczna o Kościele Lumen gentium, pkt 31, 37; Dekret o apostolstwie świeckich Aposotlicam actuositatem, pkt 26; Dekret o pasterskich zadaniach biskupów w Kościele Christus Dominus, pkt 27; Dekret o działalności

\footnotetext{
${ }^{15}$ Por. tamże, s. 33-80, 165-284.
} 
misyjnej Kościoła Ad gentes divinitus, pkt 30; Dekret o posłudze i życiu kapłanów Presbyterorum ordinis, pkt 9 oraz innymi dokumentami Kościoła: Kodeks Prawa Kanonicznego, kan. 536; Jan Paweł II: Adhortacja apostolska Christifideles laici, pkt 27. b) Przedstaw nauczanie Kościoła dotyczące parafialnych rad duszpasterskich. c) Zapoznaj się z tekstem: R. Kamiński: Parafia miejscem realizacji duszpasterstwa. W: Teologia pastoralna. Tom. 2. Teologia pastoralna szczególowa. Red. R. Kamiński. Lublin 2002 s. 50-55. d) Zapoznaj się ze statutem rady parafialnej duszpasterskiej i ekonomicznej w Twojej diecezji. e) Przedstaw krótką charakterystykę Twojej parafii oraz historię powstania parafialnej rady duszpasterskiej lub ekonomicznej. Odpowiedz m.in. na pytania: Kim są jej członkowie? Czy członkowie wspólnoty parafialnej wiedzą, kto zasiada w radach parafialnych? f) Przedstaw efekty działalności parafialnych rad w parafii Twojego pochodzenia. Wskaż ewentualne trudności w realizacji planów, źródła oraz sposoby ich rozwiązania.

Cel - student powinien znać nauczanie Kościoła dotyczące działalności rad parafialnych; kształcenie umiejętności analizy dokumentów Kościoła, praktycznego wykorzystania zdobytej wiedzy.

Wskazówka metodyczna - powyższe polecenie może być zadane jako praca zaliczeniowa.

POLECENIE 7 s. 130: a) Poszukaj w najnowszych dokumentach synodalnych Twojej diecezji wypowiedzi na temat działalności małych grup religijnych w parafii. Odpowiedz, na które aspekty zwrócono szczególną uwagę, a które może zostały pominięte? Spróbuj rozwinąć to zagadnienie. b) Wskaż zależności między wspólnotą parafialną a małymi grupami religijnymi. c) Dokonaj analizy działalności małej grupy w znanej Tobie parafii.

Cel - student powinien zdobyć umiejętność dokonywania analizy dokumentów synodalnych na w/w temat; kształcenie umiejętności prowadzenia refleksji związanej z działalnością grup religijnych funkcjonujących na terenie parafii w oparciu o teologiczne zasady duszpasterstwa oraz formułowania wniosków i postulatów pastoralnych.

POLECENIE 8 s. 134: a) Przedstaw możliwości współdziałania Twojej parafii ze szkołą i rodziną. b) Odpowiedz, jakie postrzegasz możliwości integracji kultury i wiary, w ramach działalności duszpasterskiej wśród dzieci i młodzieży w wybranym przez siebie dekanacie. c) Napisz projekt pastoralny przedstawiający współdziałanie rodziny, szkoły i parafii w obrębie dekanatu, którego celem będzie kształtowanie postawy bezinteresownej pomocy ludziom znajdującym się w potrzebie. 
Cel - student powinien posiąść umiejętność opracowania projektu duszpasterskiego na w/w temat, uwzględniając podstawowe wymogi działalności duszpasterskiej; kształcenie umiejętności prowadzenia pogłębionej refleksji dotyczącej w/w przejawów życia parafii w oparciu o teologiczne zasady duszpasterstwa, praktycznego zastosowania zdobytej wiedzy oraz formułowania wniosków i postulatów pastoralnych.

Wskazówka metodyczna - patrz: POLECENIE 2 s. 115 i POLECENIE 3 s. 117.

POLECENIE 9 s. 140: a) Odpowiedz, w jaki sposób Twoja wspólnota parafialna korzysta z wiedzy i doświadczenia osób starszych? Jak troszczy się o ludzi w podeszłym wieku? b) Znajdź parafię, w której działa „Klub Seniora” (lub inne). Opisz jego działalność. c) Przedstaw projekt pastoralny, który będzie zawierał oddziaływania duszpasterskie $\mathrm{w}$ parafii wobec osób $\mathrm{w}$ podeszłym wieku. Wykorzystaj w nim treści zawarte w liście Jana Pawła II do osób w podeszłym wieku. d) Przeprowadź wywiad ze starszymi osobami na temat życia parafii od czasów młodzieńczych do obecnych. Porównaj swoją pracę $\mathrm{z}$ innymi prezentacjami ${ }^{16}$.

Cel - student powinien dokonać analizy w/w dokumentu Kościoła; kształcenie kreatywności w zdobywaniu informacji ukazujących oddziaływanie duszpasterskie wobec osób w podeszłym wieku, kształcenie umiejętności praktycznego wykorzystania zdobytej wiedzy oraz komunikacji i pracy zespołowej.

Wskazówka metodyczna - o ile istnieją możliwości, można zaproponować, aby studenci napisali artykuł lub zredagowali jeden numer gazetki parafialnej, w całości poświęconej osobom w podeszłym wieku. Propozycję można potraktować jako pracę semestralną.

\section{Problemy współczesnej parafii}

POLECENIE 1 s. 143: a) Ustosunkuj się do przedstawionych w tekście problemów. Które z nich są nadal aktualne w polskich parafiach. b) Jakie widzisz możliwości duszpasterskiego oddziaływania w parafii? W odpowiedzi wykorzystaj wiedzę z zakresu teologii pastoralnej ogólnej, zwłaszcza tematyki dotyczącej urzeczywistniania się Kościoła w liturgii, martyrii i diakonii.

POLECENIE 2 s. 146: a) Ustosunkuj się do przedstawionych w tekście problemów. Które z nich są nadal aktualne w polskich parafiach. b) Wybierz jedno

${ }^{16}$ Zebrane materiały mogą posłużyć jako artykuły do gazetek lub kronik parafialnych. 
zagadnienie i dokonaj jego szczegółowej analizy w znanej Ci rzeczywistości parafialnej.

Cel - utrwalenie wiedzy o podstawowych miejscach działalności duszpasterskiej; rozwinięcie umiejętności: zastosowania metody badań teologii pastoralnej w analizie duszpasterskiej, prowadzenia pogłębionej refleksji związanej z działalnością duszpasterską we wspólnocie parafialnej w oparciu o zasady duszpasterstwa, praktycznego wykorzystania zdobytej wiedzy, formułowania wniosków i postulatów pastoralnych.

Wskazówka metodyczna - patrz: POLECENIE 2 s. 115 i POLECENIE 3 s. 117.

POLECENIE 3 s. 149: a) Odpowiedz, jakie dostrzegasz problemy w znanej ci rzeczywistości parafialnej w realizacji programów duszpasterskich. b) Wskaż inne pokusy (które nie są wymienione w powyższym tekście), jakim ulegają osoby zaangażowane $\mathrm{w}$ duszpasterstwie zwyczajnym.

Cel - prowadzenia pogłębionej refleksji związanej z działalnością duszpasterską we wspólnocie parafialnej w oparciu o zasady duszpasterstwa, kształcenie umiejętności krytycznej oceny rzeczywistości pastoralnej, formułowania wniosków i postulatów oraz kompetencji duszpasterskich.

POLECENIE 4 s. 154: a) Zapoznaj się z dokumentem Komisji Episkopatu Polski ds. Apostolstwa Świeckich: Dyrektorium apostolstwa świeckich, pkt 1121. Tekst znajduje się w części II: Teologia laikatu i apostolstwa, s. 288-290 ${ }^{17}$. b) Jakie dostrzegasz problemy odnośnie do udziału wiernych w życiu Twojej parafii? c) Jakie widzisz możliwości rozwiązania problemów wskazanych przez siebie oraz w tekście?

Cel - analiza dokumentu Kościoła ukazującego możliwości zaangażowania wiernych świeckich w życiu wspólnoty parafialne; kształcenie umiejętności krytycznej oceny rzeczywistości konkretnej wspólnoty parafialnej, formułowania wniosków i postulatów.

\section{Potrzeba odnowy parafii}

POLECENIE 1 s. 158: a) Wskaż aktualność zagadnień przedstawionych w powyższym tekście. Uzasadnij swoją odpowiedź. b) Porównaj przedstawione

\footnotetext{
${ }^{17} \mathrm{~W}$ podręczniku, w przypisie $\mathrm{nr} 201$ błędnie podano tytuł podrozdziału (podane strony są prawidłowe), który powinien brzmieć: Apostolstwo świeckich w Polsce w świetle II Soboru Watykańskiego.
} 
modele z wybraną parafią. Dokonaj krytycznej analizy. c) Sformułuj wnioski duszpasterskie, mające na celu ożywienie wspólnoty parafialnej.

Cel - kształcenie umiejętności praktycznego zastosowanie wiedzy o duszpasterstwie zwyczajnym, rozwinięcie umiejętności krytycznej oceny rzeczywistości wybranej wspólnoty parafialnej oraz formułowania wniosków i postulatów.

POLECENIE 2 s. 161: a) Uwzględniając powyższe treści oraz wiadomości z zakresu teologii pastoralnej napisz wytyczne dla ,idealnej” wspólnoty parafialnej. b) Porównaj zawartość swojej pracy (podpunkt a) ze znaną Ci rzeczywistością parafialną. Napisz swoje propozycje dla dalszego wzrostu Twojej wspólnoty.

Cel - student powinien umiejętność przeprowadzenia pogłębionej refleksji na w/w temat; utrwalenie zdobytej wiedzy z zakresu działalności duszpasterskiej w ramach duszpasterstwa zwyczajnego, kształcenie umiejętności formułowania wniosków i postulatów, które przyczynią się do wzrostu wspólnoty parafialnej.

POLECENIE 3 s. 165: a) Przedstaw kryteria, które uwzględnia w odnowie parafii Ruch dla Lepszego Świata. b) Które z wymienionych wskazań są realizowane w działaniach duszpasterskich w Twojej parafii? c) Zbierz jak najwięcej informacji o Twojej parafii. Jakie dostrzegasz pozytywy i braki w oddziaływaniach duszpasterskich?

POLECENIE 4 s. 167: a) Poszukaj w literaturze przedmiotu i w Internecie wiadomości o etapach odnowy parafii wypracowanych przez Ruch dla Lepszego Świata. b) Przedstaw projekt odnowy parafii zgodny z wytycznymi tego ruchu.

Cel - kształcenie umiejętności krytycznej oceny rzeczywistości parafialnej, gromadzenia niezbędnych wiadomości, przydatnych do przeprowadzanie pogłębionej refleksji na w/w tematy, formułowania wniosków i postulatów, które mogą się przyczynić do odnowy parafii.

POLECENIE 5 s. 171: a) Wykorzystując poniżej zaproponowane dokumenty Kościoła określ, czym jest parafia: Kodeks Prawa Kanonicznego Kan. $515 \S 1$; Kan. 518, 529,53; Jan Paweł II: Adhortacja apostolska Christifideles laici, pkt 26. b) Wskaż punkty wspólne pojmowania parafii i komórek ewangelizacyjnych. c) Przedstaw główne założenia parafialnych komórek ewangelizacyjnych w parafii.

Cel - student powinien znać główne założenia działalności parafialnych komórek ewangelizacyjnych; pogłębienie znajomości w/w dokumentów Ko- 
ścioła, rozwijanie umiejętności prowadzenia refleksji związanej z dziełem odnowy parafii.

POLECENIE 6 s. 175: a) Przedstaw organizację pracy w komórkach ewangelizacyjnych oraz strukturę parafii, w której są one obecne. b) Zapoznaj się z dostępną literaturą na ten temat. Oceń możliwości wykorzystania ewangelizacyjnych komórek parafialnych w Twojej parafii. c) Zorientuj się, czy w Twojej diecezji istnieją parafie, w których są parafialne komórki ewangelizacyjne. Zapoznaj się z ich działalnością (informacje możesz również uzyskać z Internetu).

Cel - student powinien przedstawić organizację pracy w komórka ewangelizacyjnych; kształcenie umiejętności: gromadzenia literatury przedmiotu i niezbędnych wiadomości, przydatnych do przeprowadzanie pogłębionej refleksji na w/w tematy, formułowania wniosków i postulatów, które mogą się przyczynić do odnowy parafii oraz komunikacji i pracy zespołowej.

Wskazówka metodyczna - pracę mogą wykonać zespoły 2-3 osobowe.

POLECENIE 7 s. 178: a) Zapoznaj się z treścią dokumentu Kościoła: Jan Paweł II: Adhortacja apostolska Ecclesia in Europa, pkt 25, 47, 50; b) Odpowiedz, w jaki sposób treści prezentowane w adhortacji odnoszą się do parafii? Jaka jest ich realizacja w Twojej parafii? Jakie widzisz przeszkody uniemożliwiające ich realizację? c) Które $z$ wymienionych propozycji są konieczne do wprowadzenia w Twojej parafii? Uzasadnij swoją odpowiedź.

Cel - pogłębienie znajomości w/w dokumentów Kościoła; rozwinięcie umiejętności prowadzenia refleksji związanej z działalnością ewangelizacyjną Kościoła oraz praktycznego wykorzystania wiedzy w ocenie rzeczywistości parafialnej.

\section{ROZDZIAŁ III: Duszpasterstwo nadzwyczajne Kościoła}

CEL OGÓLNY: przekazanie wiedzy o podstawowych wymogach i miejscach działalności duszpasterskiej; rozwinięcie umiejętności zastosowania metody badań teologii pastoralnej w analizie duszpasterskiej; kształcenie umiejętności komunikacji i pracy zespołowej.

\section{Diecezja miejscem realizacji duszpasterstwa}

POLECENIE 1 s. 186: a) Zapoznaj się z dokumentami Kościoła, na które powołuje się autor tekstu. b) Wykorzystując teksty soborowe (podpunkt a), przedstaw nauczanie Kościoła o diecezji. c) Przedstaw historię swojej diecezji (określ dowolne ramy czasowe). 
Cel - student powinien znać nauczanie Kościoła o diecezji oraz historię swojego Kościoła diecezjalnego; analiza w/w dokumentów Kościoła.

POLECENIE 2 s. 190: a) Przedstaw pracę poszczególnych referatów, które działają w Kurii Diecezjalnej Twojej diecezji. b) Przedstaw zasady, jakie powinny być uwzględniane $\mathrm{w}$ działalności pastoralnej. W odpowiedzi wykorzystaj wiadomości z zakresu podstaw teologii pastoralnej. c) Wskaż w wybranych dokumentach synodalnych Twojej diecezji, wskazania pastoralne, które świadczą o realizacji wskazanych przez Ciebie zasad. d) Dokonaj analizy wykorzystania wskazań dokumentów synodalnych w praktyce duszpasterskiej w konkretnej wspólnocie lokalnej.

Cel - student powinien: dokonać analizy w/w dokumentów Kościoła; przeprowadzić pogłębioną refleksję dotyczącą omawianego zagadnienia, posiąść umiejętność wykorzystania zdobytej wiedzy z zakresu teologii pastoralnej fundamentalnej w celu sformułowania wniosków i postulatów pastoralnych.

POLECENIE 3 s. 193: a) Zapoznaj się z dokumentami Soboru Watykańskiego II wspomnianymi w tekście. b) Przedstaw związek parafii i diecezji.

Cel - pogłębienie znajomości nauczania Soboru Watykańskiego II dotyczącego parafii i diecezji.

\section{Dekanat miejscem realizacji duszpasterstwa}

POLECENIE 1 s. 198: a) Uzupełnij historyczny aspekt dekanatu wykorzystując nauczanie soborowe i posoborowe Kościoła, np.: Dekret o pasterskich zadaniach biskupów w Kościele Christus Dominus i Kodeks Prawa Kanonicznego. b) Napisz historię dekanatu, do którego należy Twoja parafia (samodzielnie wybierz przedział czasowy).

Cel - analiza w/w dokumentów Kościoła; kształcenie umiejętności: gromadzenia literatury przedmiotu oraz niezbędnych wiadomości, przydatnych do przeprowadzanie pogłębionej refleksji na w/w tematy, formułowania wniosków i postulatów, które mogą się przyczynić do odnowy parafii oraz komunikacji i pracy zespołowej.

Wskazówka metodyczna - pracę mogą wykonać zespoły 2-3 osobowe.

POLECENIE 2 s. 199: a) Opisz, w jaki sposób rozwija się współpraca między duchownymi i laikatem w Twoim dekanacie. b) Przedstaw działania duszpasterskie podejmowane w dekanacie w okresie jednego roku liturgicznego. 
Cel - kształcenie praktycznego wykorzystania zdobytej wiedzy w zakresie omawianego zagadnienia oraz krytycznej oceny rzeczywistości związanej z działalnością duszpasterską w wybranym dekanacie.

\section{Duszpasterstwo specjalne}

POLECENIE 1 s. 200: a) Dowiedz się, jakie istnieją referaty duszpasterstwa nadzwyczajnego w Twojej diecezji. Przedstaw działalność wybranego przez siebie referatu. W prezentacji uwzględnij współpracę na linii kuria - dekanat. b) Przedstaw działalność wybranego dekanatu w ramach duszpasterstwa nadzwyczajnego lub wskaż możliwości poszerzenia owej działalności. Jakie dostrzegasz problemy w formie posługi pastoralnej? c) Wybierz jeden z przejawów duszpasterstwa nadzwyczajnego. Przedstaw jego działalność w wybranej diecezji.

Cel - student powinien przedstawić działalność referatu; kształcenie umiejętności krytycznej oceny działalności Kościoła w ramach duszpasterstwa nadzwyczajnego oraz formułowania wniosków i postulatów pastoralnych.

POLECENIE 2 s. 204: a) Zapoznaj się z dokumentami Kościoła wspomnianymi w powyższym tekście. b) Oceń przedstawioną propozycję działalności duszpasterstwa rodzin. c) Przedstaw działalność Duszpasterstwa Rodzin w Twojej diecezji. Które $\mathrm{z}$ wymienionych propozycji są możliwe do zrealizowania w najbliższym czasie? d) Przedstaw zagadnienia Duszpasterstwa Rodzin w najnowszych dokumentach synodalnych Twojej diecezji.

Cel - analiza wskazanych dokumentów Kościoła; kształcenie umiejętności prowadzenia pogłębionej refleksji związanej z działalnością Duszpasterstwa Rodzin w diecezji, formułowania wniosków i postulatów pastoralnych oraz podstawowych kompetencji duszpasterskich.

POLECENIE 3 s. 208: a) Wskaż podstawowe kierunki i zadania duszpasterstwa młodzieży. b) Zapoznaj się z przemówieniami Papieża z ostatnich Światowych Dni Młodzieży. c) Napisz wytyczne, które mogą być wykorzystane w pracy duszpasterskiej z młodzieżą. d) Wskaż przejawy duszpasterstwa młodzieży, które realizują przesłanie Ojca Świętego.

Cel - student powinien znać treść przemówień papieskich wygłoszonych podczas Światowych Dni Młodzieży; kształcenie umiejętności analizy dokumentów Kościoła oraz wykorzystania zdobytej wiedzy w ocenie rzeczywistości duszpasterskiej.

POLECENIE 4 s. 211: a) Przedstaw charakterystykę wybranego przez siebie ruchu lub stowarzyszenia obecnego w Twojej parafii/diecezji. W odpowiedzi uwzględnij formację członków oraz wskaż na problemy, z jakimi się spotykają 
jego członkowie. b) Poszukaj w dokumentach synodalnych, statystykach, prasie informacji dotyczących działalności ruchów i stowarzyszeń katolickich działających w Twojej diecezji. Przedstaw ich ogólną charakterystykę na tle całej diecezji. c) Odpowiedz, w jaki sposób ruchy i stowarzyszenia katolickie mogą pogłębiać odkrywanie na nowo specyfiki powołania i misji świeckich w Kościele. Wykorzystaj treści zawarte w 2 części podręcznika: Teologia laikatu i apostolstwa.

$\mathrm{Cel}$ - student powinien przedstawić charakterystykę wybranego przez siebie ruchu lub stowarzyszenia katolickiego; kształcenie umiejętności gromadzenia literatury przedmiotu i niezbędnych wiadomości, przydatnych do przeprowadzanie pogłębionej refleksji na w/w tematy, formułowania wniosków i postulatów oraz komunikacji i pracy zespołowej.

Wskazówka metodyczna - pracę mogą wykonać zespoły 2-3 osobowe.

POLECENIE 5 s. 215: a) Przedstaw działalność ośrodka duszpasterstwa akademickiego. Wykorzystaj proces badawczy teologii pastoralnej, zawarty $\mathrm{w}$ pierwszej części podręcznika (rozdział 2: Metodologia nauk pastoralnych, s. 3080). b) Dokonaj analizy działalności ośrodka duszpasterstwa akademickiego uwzględniając w sposób szczególny wskazania zawarte w powyższym tekście. Wskaż przyczyny ewentualnych trudności oraz możliwości ich rozwiązania.

Cel - rozwinięcie umiejętności zastosowania metody badań teologii pastoralnej $\mathrm{w}$ analizie duszpasterskiej na wskazany temat, prowadzenia pogłębionej refleksji związanej z działalnością Kościoła w oparciu o teologiczne zasady duszpasterstwa oraz formułowania wniosków i postulatów.

POLECENIE 6 s. 219: a) Dokonaj krytycznej analizy pielgrzymki, w której uczestniczyłeś (lub po przeprowadzeniu wywiadu z pielgrzymem). W opracowaniu uwzględnij powyższe treści. b) Opracuj szczegółowo projekt pastoralny, który będzie zawierał 6 etapów pielgrzymki.

Cel - student powinien opracować w/w projekt pastoralny; kształcenie umiejętności zastosowania metody badań teologii pastoralnej w analizie duszpasterskiej na wskazany temat, prowadzenia pogłębionej refleksji związanej z działalnością Kościoła w oparciu o teologiczne zasady duszpasterstwa oraz formułowania wniosków i postulatów.

POLECENIE 7 s. 223: a) Napisz wytyczne przeznaczone dla sportowców, trenerów oraz duszpasterzy sportu, które będą pomocne w ich działalności. W pracy uwzględnij nauczanie Kościoła. Wiele pomocnych materiałów znajdziesz na stronie internetowej: http://www.sport.episkopat.pl/struktura/ b) Przedstaw 
działalność duszpasterstwa sportowców o zasięgu ogólnopolskim lub diecezjalnym. Napisz, jakie widzisz możliwości dalszego rozwoju tej formy posługi duszpasterskiej.

Cel - student powinien przedstawić działalność duszpasterstwa sportowców o zasięgu ogólnopolskim lub diecezjalnym; kształcenie kreatywności w zdobywaniu informacji ukazujących działania duszpasterskie wśród sportowców oraz umiejętności krytycznej oceny omawianej dzielności, formułowania wniosków i postulatów.

POLECENIE 8 s. 229: a) Przedstaw działalność duszpasterską w parafii wśród chorych. Jakie widzisz możliwości dalszego rozwoju tej działalności. b) Zaznaj się działalnością hospicjum. Na jakie trudności napotykają osoby posługujące chorym.

Cel - student powinien przeprowadzić pogłębioną refleksję dotyczącą omawianego zagadnienia oraz wykazać umiejętność wykorzystania zdobytej wiedzy z zakresu teologii pastoralnej fundamentalnej $\mathrm{w}$ celu sformułowania wniosków i postulatów pastoralnych.

\section{Duszpasterstwo specjalistyczne - ogólna charakterystyka}

POLECENIE 1 s. 233: a) Przedstaw działalność wybranej przez siebie wspólnoty zakonnej męskiej lub żeńskiej, której charyzmatem jest opieka nad osobami nieprzystosowanymi prawnie i społecznie. b) Dokonaj szczegółowej analizy wybranego przejawu duszpasterstwa specjalistycznego w Twojej diecezji.

Cel - rozwinięcie umiejętności zastosowania metody badań teologii pastoralnej $\mathrm{w}$ analizie duszpasterskiej na wskazany temat, prowadzenia pogłębionej refleksji związanej z działalnością Kościoła w oparciu o teologiczne zasady duszpasterstwa oraz formułowania wniosków i postulatów.

Wskazówka metodyczna - przed przystąpienie do wykonania zadania student powinien powtórzyć wiadomości związane z procesem badawczym teologii pastoralnej $^{18}$.

POLECENIE 2 s. 236: a) Przeprowadź wywiad z osobą angażującą się w działalność duszpasterstwa specjalistycznego. Dowiedz się, z jakim problemami się najczęściej spotyka, co jest najtrudniejsze w tej służbie oraz jakie widzi możliwości dalszego rozwoju? b) Poszukaj w literaturze przedmiotu oraz prasie los. $30-80$.

${ }^{18}$ Por. J. K u r o s z: Teologia pastoralna. Materiały do ćwiczeń. Część pierwsza ..., dz. cyt., 
kalnej informacji o działalności ośrodków działających w ramach duszpasterstwa specjalistycznego. Przedstaw działalność jednego z nich.

POLECENIE 3 s. 241: a) Przedstaw posługę prezbitera w wybranym przez siebie zakładzie penitencjarnym. b) Przeprowadź wywiad z kapelanem więzienia na temat dostrzegalnych efektów pracy wśród więźniów oraz współpracy z osobami świeckimi. c) Dowiedz się, jak wygląda pomoc postpenitencjarna w Twojej diecezji. Zwróć szczególną uwagę na pojawiające się trudności i sposoby ich rozwiązywania. d) Dowiedz się, czy w Twojej diecezji są członkowie „Bractwa więziennego". Jeżeli tak, opisz ich działalność, uwzględniając problemy z jakimi się spotykają członkowie bractwa, jak i więźniowie.

Cel - student powinien przedstawić charakterystykę wybranej działalności w ramach duszpasterstwa specjalistycznego; kształcenie umiejętności gromadzenia literatury przedmiotu i niezbędnych wiadomości, przydatnych do przeprowadzanie pogłębionej refleksji na w/w tematy, formułowania wniosków i postulatów oraz komunikacji i pracy zespołowej.

Wskazówka metodyczna - pracę mogą wykonać zespoły 2-3 osobowe.

POLECENIE 4 s. 244: a) Odpowiedz, jakie działania są podejmowane (np. przez Caritas) w wybranej diecezji mające na celu pomoc osobom uzależnionym od narkotyków i innych używek? Stwórz listę podejmowanych działań wśród osób uzależnionych. b) Wybierz z listy jedno zagadnienie (podpunkt a) i opisz szczegółowo działania, podejmowane w wybrany przez siebie okresie.

POLECENIE 5 s. 246: a) Odpowiedz, jakie działania mające na celu pomoc osobom bezdomnym są podejmowane (np. przez Caritas) w wybranej diecezji? Stwórz listę zawierającą adresy placówek oraz charakter pomocy. b) Wybierz z listy jedno zagadnienie (podpunkt a) i opisz szczegółowo podejmowane działania w wybranych przez siebie ramach czasowych.

Cel - student powinien zaprezentować działalność Kościoła w zakresie omawianego zagadnienia; kształcenie umiejętności wykorzystania zdobytej wiedzy w ocenie działalności Kościoła w ramach duszpasterstwa specjalistycznego, formułowania wniosków i postulatów.

\section{Cele i efekty ksztalcenia w ramach ćwiczeń $\mathrm{z}$ teologii laikatu i apostolstwa}

Ćwiczenia z teologii laikatu i apostolstwa mają określone cele, które wpisują się w cele ogólne zajęć dydaktycznych prowadzonych w ramach kształcenia 
pastoralnego. W prezentowanych materiałach do ćwiczeń, w części dotyczącej teologii laikatu i apostolstwa, treści tam zawarte powinny pomóc w ich realizacji, tj.: przekazaniu wiedzy związanej z teologicznymi podstawami posłannictwem świeckich wiernych w Kościele, zapoznaniu w stopniu rozszerzonym z analizą historyczną dotycząca roli laikatu, uwrażliwieniu na posłannictwo i apostolstwo świeckich, które realizowane jest w dwóch płaszczyznach: w Kościele oraz w świecie; rozwinięciu umiejętności prowadzenia pogłębionej refleksji związanej z zaangażowaniem laikatu w obecnym czasie, kształceniu umiejętności interpretacji dokumentów Kościoła i doboru literatury przedmiotu, rozwinięciu umiejętności komunikacji i pracy zespołowej.

Efekty kształcenia powinny się przejawiać w zakresie:

- wiedzy: student powinien znać teologiczne podstawy posłannictwa świeckich wiernych oraz posiąść zdolność określania płaszczyzn i form apostolstwa wiernych świeckich w Kościele i świecie,

- umiejętności: student powinien zdobyć umiejętność dokonywania historycznej analizy roli laikatu w historii Kościoła i jej odniesienia do współczesności, posługiwać się zdobytą wiedzą w celu dokonania analizy współczesnego zaangażowania laikatu w Kościele i świecie, formułować wnioski dotyczące zaangażowania laikatu w Kościele, a także korzystać z dokumentów Kościoła i literatury przedmiotu

- kompetencji: student powinien posiadać pogłębioną zdolność refleksji dotyczącej zaangażowania laikatu w Kościele i świecie, być wrażliwym na wymogi racjonalności dyskursu teologicznego oraz potrafić współpracować z duchownymi i świeckimi w posłudze pastoralnej Kościoła.

\section{Wskazówki metodyczne}

\section{ROZDZIAL I: Podstawowe pojęcia}

POLECENIE 1 s. 260: a) Zapoznaj się z treścią dokumentów: Sobór Watykański II: Konstytucja dogmatyczna o Kościele Lumen gentium, pkt 9-11, 3133; Jan Paweł II: Adhortacja apostolska Christifideles laici, rozdz. 1. b) Wskaż różnice i podobieństwa dotyczące pojęcia świeckiego, zaprezentowane przez autorów powyższych tekstów. c) Na podstawie tekstu 1 i 2 oraz wskazanych dokumentów Kościoła przedstaw pojęcie świeckiego oraz jego zadania w Kościele i świecie. d) Stwórz własny lub uzupełnij schemat nr 1 przedstawiający najważniejsze treści I rozdz. Adhortacji apostolskiej Christifideles laici.

Cel - student powinien przedstawić zagadnienie związane z określeniem definicji świeckiego oraz zadań świeckiego w Kościele i świecie, zawarte w nau- 
czaniu Kościoła, kształcenie umiejętności: prowadzenia pogłębionej refleksji dotyczącej laikatu.

Wskazówka metodyczna - przykładowy schemat zamieszczono w załączniku nr 1 .

POLECENIE 2 s. 264: a) Zapoznaj się z treścią dokumentów: Sobór Watykański II: Dekret o apostolstwie świeckich Apostolicam acutositatem, pkt 2; Katechizm Kościoła Katolickiego, pkt 863-865; b) Przedstaw zwięzłą genezę i rozwój pojęcia apostolstwo. c) Wskaż cztery istotne elementy apostolstwa oraz wynikające z nich konsekwencje. d) Wskaż zależności, które istniały między miejscem świeckiego w Kościele, a apostolstwem. e) Wykorzystując dostępną literaturę przedmiotu oraz nauczanie Kościoła, wskaż ewentualne różnice oraz zależności między pojęciami: apostolstwo, misja, ewangelizacja i przepowiadanie. f) Uzasadnij zdanie: Apostolstwo świeckich może się wtaściwie rozwijać w małych komórkach, gdzie równocześnie ciagle trwa proces formacji, bo on nigdy nie może się skończyćc ${ }^{19}$.

Cel - student powinien przedstawić apostolstwo w/w zakresie; kształcenie umiejętności doboru odpowiedniej literatury przedmiotu i niezbędnych wiadomości, przydatnych do przeprowadzanie pogłębionej refleksji na w/w tematy, formułowania wniosków i postulatów oraz komunikacji i pracy zespołowej.

Wskazówka metodyczna - praca w zespole 2-3 osobowym, polecenie z podpunktu f) można wykorzystać jako temat pracy podsumowującej zagadnienie apostolstwa.

POLECENIE 3 s. 266: a) Wymień rodzaje apostolstwa. b) Wskaż przejawy apostolskiego zaangażowania grup członków Kościoła, wymienionych w powyższych tekstach.

$\mathrm{Cel}$ - student powinien znać rodzaje apostolstwa i przedstawić ich charakterystykę; kształcenie umiejętności krytycznej oceny przejawów apostolskiego zaangażowania laikatu w działalności apostolskiej.

\section{ROZDZIAŁ II: Świeccy w Kościele na przestrzeni wieków}

POLECENIE 1 s. 271: a) Napisz własne zakończenie powyższego tekstu, uwzględniając nauczanie Kościoła od czasu Soboru Watykańskiego II do chwili obecnej. Możesz skorzystać z następujących dokumentów: Instrukcja o niektórych kwestiach dotyczacych wspótpracy wiernych świeckich $w$ ministerialnej

\footnotetext{
${ }^{19}$ F. B l a c h n i c k i: Godziny Taboru. Carlsberg - Lublin 1989 s. 65.
} 
postudze kapłanów. „L'Osservatore Romano”. Wydanie polskie. R. 19: $1998 \mathrm{nr}$ 12 (208) s. 34-40; Jan Paweł II: Adhortacja apostolska Christifideles laici, rozdz. 1-3; Kongregacja Nauki Wiary: Nota doktrynalna o niektórych aspektach działalności i postępowaniu katolików w życiu publicznym. ,, L'Osservatore Romano". Wydanie polskie. R. 24: 2003 nr 2 (250) s. 49-54; Sobór Watykański II: Dekret o apostolstwie świeckich Apostolicam actuositatem, pkt 7, 13-14; Sobór Watykański II: Dekret o działalności misyjnej Kościoła Ad gentes divinitus, pkt 21; Sobór Watykański II: Konstytucja dogmatyczna o Kościele Lumen gentium, pkt. 9-13, 31, 33; Sobór Watykański II: Konstytucja duszpasterska o Kościele w świecie współczesnym Gaudium et spes, pkt 4; Paweł VI: Adhortacja apostolska Evangelii nuntiandi, pkt. 70, 73. b) Porównaj swoją pracę z artykułem ks. Józefa Michalika. Ustosunkuj się do różnic, które dostrzeżesz między dwoma tekstami. c) Stwórz wykres graficzny prezentujący historię miejsca świeckiego Kościele.

Cel - zapoznanie (przypomnienie) z treścią w/w dokumentów, kształcenie umiejętności analizy i syntezy nauczania Kościoła w zakresie teologii laikatu.

POLECENIE 2 s. 276: a) Przeczytaj uważnie teksty 1-7. b) Napisz własne tytuły do powyższych fragmentów. c) Połącz autora lub miejsce powstania (c 1) z tytułem (2 c): c 1: autor/miejsce powstania: M. Skonieczny, II Sobór Watykański, Karol Wojtyła, Grzegorz Wielki, Sobór Trydencki, Gracjan, Jan Paweł II; c 2: tytuł: Apostolstwo świeckich, Dekret Gracjana, Ksiega reguly pasterskiej, Konstytucja duszpasterska o Kościele w świecie współczesnym Gaudium et spes (pkt 43), List apostolski Novo millennio ineunte (pkt 45-46), Na odcinku Parafialnej Akcji katolickiej, Sesja XXIII. Nauka o sakramencie kapłaństwa. d) Ułóż teksty 2-8 w kolejności chronologicznej - możesz wykorzystać Tabelę nr 1.

Cel - zapoznanie z tekstami ukazującymi miejsce laikatu w Kościele na przestrzeni wieków, utrwalenie wiadomości dotyczących w/w zagadnienia.

Wskazówka metodyczna - podobne POLECENIE zostało zamieszczone w artykule dotyczącym zajęć dydaktycznych na wyższych uczelniach ${ }^{20}$.

ODPOWIEDZI: Tekst 1: Jan Paweł II: List apostolski Novo millennio ineunte (pkt 45-46); Tekst 2: Konstytucja duszpasterska o Kościele w świecie współczesnym Gaudium et spes (pkt 43); Tekst 3: Gracjan: Dekret Gracjana; Tekst 4: M. Skonieczny: Na odcinku Parafialnej Akcji katolickiej; Tekst 5: Sobór Trydencki: Sesja XXIII. Nauka o sakramencie kaptaństwa; Tekst 6: Karol Wojtyła: Apostolstwo świeckich; Tekst 7: Grzegorz Wielki: Księga reguły pasterskiej.

Układ chronologiczny: nr tekstu: 7, 3, 5, 4, 2, 6, 1.

\footnotetext{
${ }^{20}$ Por. J. K u ro s z: Ćwiczenia z teologii pastoralnej dla studentów..., dz. cyt., s. 354-360.
} 
POLECENIE 3 s. 280: a) Uzupełnij w sposób logiczny powyższy tekst 1 lub 2. b) Porównaj swoje odpowiedzi $\mathrm{z}$ tekstem oryginalnym. Zastanów się nad ewentualnymi różnicami w udzielonych odpowiedziach.

Cel - dwie możliwości: wprowadzanie w tematykę zajęć i sprawdzenie przez studenta wiedzy dotyczącej laikatu lub utrwalenie wiedzy związanej z powyższym tematem.

Wskazówka metodyczna - studenci wykonują polecenie podczas ćwiczeń; w trakcie wykonywania zadania należy bardziej zwrócić uwagę na logiczne uzupełnienie brakujących sformułowań, dopiero później na zgodność z oryginalnym tekstem. Po uzupełnieniu tekstu zespoły 2-3 osobowe porównują swoje odpowiedzi, następnie cała grupa porównuje swoje prace $\mathrm{z}$ tekstem oryginalnym.

UWAGA: teksty umieszczono w załączniku 2:

$\mathrm{W}$ związku z powyższym zagadnieniem można również wykorzystać materiał z części: Teologia pastoralna szczegółowa - wybrane zagadnienia, rozdział 1: Duszpasterstwo w misji Kościoła (podrozdział: Duszpasterstwo działalnościa zespołowa), POLECENIE 1 s. 61.

\section{ROZDZIAL III: Apostolstwo świeckich}

POLECENIE 1 s. 283: a) Zapoznaj się z treścią dokumentów Soboru Watykańskiego II: Dekretem o apostolstwie świeckich Apostolicam actuositatem; Konstytucją dogmatyczną o Kościele Lumen gentium, pkt 9-17, 31, 33; Dekretem o działalności misyjnej Kościoła Ad gentes divinitus, pkt 21. b) Scharakteryzuj pojęcie świeckiego oraz jego powołanie do apostolstwa. c) Napisz własne tytuły do poszczególnych grup tematycznych omawianych dokumentów. d) Rozwiń poszczególne hasła w schemacie nr 2 lub utwórz własny, który będzie przedstawiał najważniejsze treści wskazanych powyżej dokumentów. e) Wskaż podstawy apostolskiego zaangażowania świeckich. f) Odpowiedz na pytanie zawarte w ostatnim zdaniu cytowanego tekstu. Uzasadnij swoją odpowiedź.

Cel - student powinien znać nauczanie Kościoła na w/w temat; kształtowanie umiejętności interpretacji dokumentów Kościoła, prowadzenia pogłębionej refleksji związanej z zaangażowaniem laikatu w obecnym czasie oraz komunikacji i pracy zespołowej.

Wskazówka metodyczna - POLECENIE wykonują zespoły 2-3 osobowe.

UWAGA: Schemat zamieszczono w załączniku 3. 
POLECENIE 2 s. 288: a) Wybierz zagadnienie z Dekretu o apostolstwie świeckich Apostolicam actuositatem (zob. schemat nr 2 ) lub jeden rozdział. b) Zapoznaj się z Konstytucją duszpasterską o Kościele w świecie współczesnym Gaudium et spes i wyszukaj w niej treści, które będą komentarzem do wybranego przez Ciebie zagadnienia lub fragmentu dokumentu. c) Uwzględniając wskazówki kard. Karola Wojtyły, wskaż formy apostolstwa, które dostrzegasz w życiu codziennym.

Cel - zapoznanie (pogłębienie) z treścią w/w dokumentów; kształcenie umiejętności interpretacji dokumentów Kościoła, krytycznej oceny zaangażowania laikatu w apostolstwo Kościoła oraz prowadzenia pogłębionej refleksji związanej z omawianym zagadnieniem.

POLECENIE 3 s. 290: a) Porównaj znaną Ci rzeczywistość parafialną z treścią Dyrektorium apostolstwa świeckich. Wskaż postulaty, które są realizowane oraz oceń ich skuteczność. b) Z jakimi współczesnymi problemami spotykają się duszpasterze w parafii, o których nie wspomina dokument z 1969 r.? c) Wykorzystując schemat nr 2 zawierający podstawowe treści Dekretu o apostolstwie świeckich Apostolicam actuositatem, rozwiń go o wybrane przez siebie zagadnienie, po czym uzupełnij go informacjami dotyczącymi znanej Ci rzeczywistości parafialnej. d) W wybranym przez siebie zagadnieniu (podpunkt c) zaznacz w schemacie znakiem ,!’” te treści, które wg Ciebie są najważniejsze, zaś znakiem „?”, to, co Twoim zdaniem nie jest realizowane w Kościele w Polsce lub jest najtrudniejsze do realizacji. Uzasadnij swoje wybory. e) Dokonaj adaptacji treści Dekretu o apostolstwie świeckich Apostolicam actuositatem do warunków i możliwości parafii miejsca Twojego zamieszkania. Możesz wykorzystać proponowany schemat.

Cel - powinien znać treść w/w dokumentów; kształcenie umiejętności prowadzenia pogłębionej refleksji związanej z zaangażowaniem laikatu w obecnym czasie, przeprowadzania pogłębionej analizy dokumentów Kościoła oraz komunikacji i pracy zespołowej.

Wskazówka metodyczna - praca w zespołach 2-3 osobowych.

POLECENIE 4 s. 294: a) Zapoznaj się ze wszystkimi tekstami soborowymi wskazanymi w tekście 2 oraz: Jan Paweł II: Adhortacja apostolska Christifideles laici, pkt 22-24; Kodeks Prawa Kanonicznego 230§ 3; Dekret o apostolstwie świeckich Apostolicam actuositatem, pkt 3. b) Scharakteryzuj charyzmat i posługę, przedstawione w tych dokumentach Kościoła. c) Wskaż konkretne przykłady wykorzystania charyzmatów i posług w różnych formach apostolstwa. 
Cel - student powinien dokonać charakterystyki charyzmatu i posługi; kształcenie umiejętności praktycznego zastosowania zdobytej wiedzy.

POLECENIE 5 s. 297: a) Zapoznaj się z drugim rozdziałem adhortacji apostolskiej Jana Pawła II Christifideles laici. b) Stwórz własny lub uzupełnij schemat $\mathrm{nr} 3$, przedstawiający najważniejsze treści drugiego rozdziału wspomnianego dokumentu. c) Wykorzystując treści dokumentu oraz tekstu 3 wskaż, które przejawy życia eklezjalnej wspólnoty w diecezji lub parafii miejsca Twojego zamieszkania, wymagają odnowy zgodnej z nauczaniem Kościoła. d) W jaki sposób kapłani i laikat mogą wspierać rozwój i wzajemne dopełnianie się apostolstwa i duszpasterstwa w Kościele. e) Napisz, jak laikat widziany w perspektywie Konstytucji dogmatycznej o Kościele Lumen gentium (zwłaszcza pkt 31) oraz Adhortacji apostolskiej Christifideles laici (rozdz. 2) wpisuje się w życie i działalność Kościoła.

$\mathrm{Cel}$ - zapoznanie (przypomnienie) z treścią w/w dokumentów: porównanie nauczania Kościoła ze znaną rzeczywistością w diecezji lub parafii; kształcenie umiejętności prowadzenia pogłębionej refleksji nad zaangażowaniem laikatu, praktycznego wykorzystania zdobytej wiedzy oraz komunikacji i pracy zespołowej.

Wskazówka metodyczna - praca w zespołach 2-3 osobowych.

UWAGA: schemat zamieszczono w załączniku 4.

\section{ROZDZIAL IV: Realizacja zadań apostolskich}

POLECENIE 1 s. 303: a) Wskaż przejawy zaangażowania świeckich w Kościele we Francji i porównaj je z treścią z Adhortacji apostolskiej Christifideles laici, zwłaszcza rozdz. 1-3. b) Zapoznaj się z sytuacją Kościoła we Francji (możesz wykorzystać pełny tekst powyższego artykułu). Wskaż cechy wspólne oraz różnice pomiędzy sytuacją Kościoła w Polsce i we Francji. Spróbuj wskazać odmienne sposoby procesu podejmowania współodpowiedzialności za Kościół laikatu w tych krajach europejskich. c) Zastanów się, czy w polskich warunkach jest potrzeba oraz możliwość większego zaangażowania laikatu w życie Kościoła. Wskaż obszary działalności duszpasterskiej, w których obecność laikatu byłaby wskazana. Uzasadnij swoją odpowiedź.

Cel - kształcenie umiejętności pogłębionej analizy duszpasterskiej rzeczywistości związanej z zaangażowaniem laikatu oraz formułowania wniosków i postulatów oraz komunikacji i pracy zespołowej.

Wskazówka metodyczna - praca w zespołach 2-3 osobowych. 
POLECENIE 2 s. 306: a) Uzupełnij schemat nr 4 tak, by zawierał podstawowe treści Adhortacji apostolskiej Christifideles laici, rozdz. 3. b) Przedstaw szczegółowo wybrane przez siebie zagadnienie z tego schematu. c) Porównaj treści ze schematu $\mathrm{z}$ wybranymi przez siebie przejawami w życiu społecznym.

Cel - zapoznanie (przypomnienie) z treścią w/w dokumentu; porównanie nauczania Kościoła ze znaną rzeczywistością Kościoła i najbliższego otoczenia; kształcenie umiejętności prowadzenia pogłębionej refleksji nad zaangażowaniem laikatu w życiu Kościoła i społeczeństwa.

POLECENIE 3 s. 309: a) Zapoznaj się (przypomnij) z treścią dokumentu Kościoła: Jan Paweł II: Adhortacja apostolska Christifideles laici, rozdz. 3; Odpowiedz, do jakich zadań w społeczeństwie wezwani się katolicy. b) Które z wymienionych przez Papieża zadań w społeczeństwie domagają się większego zaangażowania laikatu w polskiej rzeczywistości? c) Wybierz jedną dziedzinę z życia Kościoła lub społeczeństwa, o których wspomina Papież Benedykt XVI. Opisz szczegółowo ich realizację w Twoim środowisku. Dokonaj krytycznej analizy podjętych działań.

Cel - utrwalenie i pogłębienie wiedzy dotyczącej zaangażowania laikatu w Kościele i świecie; kształcenie umiejętności prowadzenia pogłębionej refleksji na w/w temat, posługiwania się zdobyta wiedzą w celu dokonania analizy współczesnego zaangażowania laikatu.

POLECENIE 4 s. 314: a) Zapoznaj się z treścią następujących dokumentów Kościoła : Konstytucja duszpasterska o Kościele w świecie współczesnym Gaudium et spes, pkt 36-37, 42-43; Jan Paweł II: Adhortacja apostolska Christifideles laici, rozdz. 3. b) Przedstaw zasady, którymi powinni się kierować katolicy angażujący się w działalność społeczną i polityczną. c) Wybierz jedną sytuację, która miała miejsce w życiu politycznym lub społecznym (wykorzystaj materiały z prasy). Uwzględniając proponowane dokumenty Kościoła, dokonaj krytycznej analizy zaistniałej sytuacji. Sformułuj wnioski będą odzwierciedlały nauczanie Kościoła.

Cel - student powinien znać nauczanie Kościoła o zasadach zaangażowania laikatu w życiu politycznym i społecznym; kształcenie umiejętności posługiwania się zdobytą wiedzą w zakresie w/w tematu, prowadzenia pogłębionej refleksji nad zaangażowaniem laikatu w Kościele i świecie oraz formułowania wniosków i postulatów. 


\section{ROZDZIAŁ V: Prezbiterzy i świeccy we wspólnocie Kościoła}

POLECENIE 1 s. 316: a) Zapoznaj się z następującymi dokumentami Kościoła: Instrukcja o niektórych kwestiach dotyczacych wspótpracy wiernych świeckich w ministerialnej postudze kaptanów. „L'Osservatore Romano”. Wydanie polskie. R. 19: 1998 nr 12 (208) s. 34 art. 1; Jan Paweł II: Adhortacja apostolska Christifideles laici, pkt 15-16. b) Uwzględniając nauczanie Kościoła, scharakteryzuj prawidłową relację między duchowieństwem i laikatem. c) Wskaż osoby, które mogą przyjmować tytuł: duszpasterz, moderator, kapelan, koordynator.

Cel - student powinien znać nauczanie Kościoła o prawidłowej relacji, jaka powinna istnieć między duchowieństwem i laikatem; kształcenie umiejętności posługiwania się zdobytą wiedzą, zwłaszcza w prawidłowej ocenie kościelnej rzeczywistości związanej z omawianym zagadnieniem.

POLECENIE 2 s. 321: a) Zapoznaj się z dokumentami Kościoła: Kongregacja ds. Spraw Duchowieństwa: Instrukcja Kapłan, pasterz i przewodnik wspólnoty parafialnej [2002]. Poznań 2002 pkt 1-4; Kodeks Prawa Kanonicznego, kann.: 208-223; $225 \S 1-2 ; 226-227 ; 228 \S 2 ; 229 ; 231 \S 1-2$. b) Wskaż podobieństwa i różnice jakie istnieją między kapłaństwem wspólnym, powszechnym, urzędowym, służebnym. Wykorzystaj dokumenty Kościoła zamieszczone w bibliografii na końcu rozdziału.

Cel - student powinien znać w/w w dokumenty Kościoła i odpowiedzieć na powyższe pytania; kształcenie umiejętności korzystania z dokumentów Kościoła i literatury przedmiotu $\mathrm{w}$ zakresie omawianego zagadnienia.

Wskazówka metodyczna - można wykorzystać materiał z części: Teologia pastoralna szczegótowa - wybrane zagadnienia, podrozdział Duszpasterstwo działalnościa zorganizowana, POLECENIE 3 s. 33.

POLECENIE 3 s. 325: a) Zastanów się nad poprawnością stwierdzenia: $\mathrm{Ka}$ plaństwo ministerialne znaczy tyle samo ( $w$ petni wyraża), co kaptaństwo stużebne. Uzasadnij swoją odpowiedź. b) Przedstaw rozwój zagadnienia związanego z kapłaństwem od czasu Soboru Watykańskiego II. Pomocne będą m.in. następujące teksty: Sobór Watykański II: Konstytucja dogmatyczna o Kościele Lumen gentium, pkt 10-11, 31; Sobór Watykański II: Dekret o apostolstwie świeckich Apostolicam actuositatem; Jan Paweł II: Adhortacja apostolska Christifideles laici, pkt 21-23.

Cel - utrwalenie i pogłębienie wiadomości związanych z kapłaństwem; analiza dokumentów Kościoła. 
POLECENIE 4 s. 328: a) Zapoznaj się z następującymi dokumentami Kościoła: Kodeks Prawa Kanonicznego, kan. 230 § 1-3; Instrukcja o niektórych kwestiach dotyczacych wspótpracy wiernych świeckich $w$ ministerialnej postudze kapłanów. „L’Osservatore Romano”. Wydanie polskie. R. 19: 1998 nr 12 (208) s. 30-40; Jan Paweł II: Adhortacja apostolska Christifideles laici, pkt 16. b) Wskaż różnice między charyzmatem, posługą i funkcją. c) Zapoznaj się (lub przypomnij) treść Tekstu 2 z podrozdziału: Podstawowe pojęcia. Odpowiedz: Dlaczego pytanie o miejsce świeckich w Kościele zawiera w sobie pytania o kształt Kościoła i współodpowiedzialności za niego? d) Jakie niebezpieczeństwa niesie brak świadomości Kościoła jako ciała Chrystusa, w którym wielorakie posługi odzwierciedlają różnorodność i bogactwo członków Kościoła? e) Porównaj treść dokumentów z podpunktu a) z zaangażowaniem świeckich w Kościele. Sformułuj wnioski.

Cel - zapoznanie (pogłębienie) z treścią w/w dokumentów; kształcenie umiejętności: analizy dokumentów Kościoła, wykorzystania zdobytej wiedzy w ocenie eklezjalnej rzeczywistości, prowadzenia pogłębionej refleksji dotyczącej współpracy laikatu z prezbiterami, formułowania wniosków i postulatów.

POLECENIE 5 s. 331: a) Porównaj przedstawione w tekście relacje między kapłanami i świeckimi ze znaną Ci rzeczywistością parafialną. b) Uwzględniając nauczanie Kościoła, sformułuj wnioski duszpasterskie dotyczące współpracy duchowieństwa i laikatu w parafii.

Cel - kształcenie umiejętności wykorzystania zdobytej wiedzy w ocenie eklezjalnej rzeczywistości, prowadzenia pogłębionej refleksji dotyczącej współpracy laikatu z prezbiterami oraz formułowania wniosków i postulatów.

Zaproponowane polecenia dla studentów, z teologii pastoralnej szczegółowej oraz teologii laikatu i apostolstwa powinny być wykonane w całości bądź częściowo przed planowanymi zajęciami dydaktycznymi. Warto też pamiętać, że podział studentów na 2-3 osobowe zespoły gwarantuje, że w wykonanie poleceń będą zaangażowane wszystkie osoby. Ponadto istnieje większe prawdopodobieństwo kształcenia umiejętności komunikacji i pracy zespołowej.

Wskazówki metodyczne są jedynie propozycją. Istnieje o wiele więcej możliwości łączenie poszczególnych poleceń i tekstów dla tematów zawartych w obu częściach Materiałów do ćwiczeń. W niniejszym artykule wskazano jedynie przykładowe propozycje, gdyż od prowadzącego ćwiczenia, jego kompetencji, kreatywności, realizowanego programu oraz od uczestników ćwiczeń, zależy ostateczny kształt przeprowadzonych zajęć. 
ZALĄCZNIK 1:

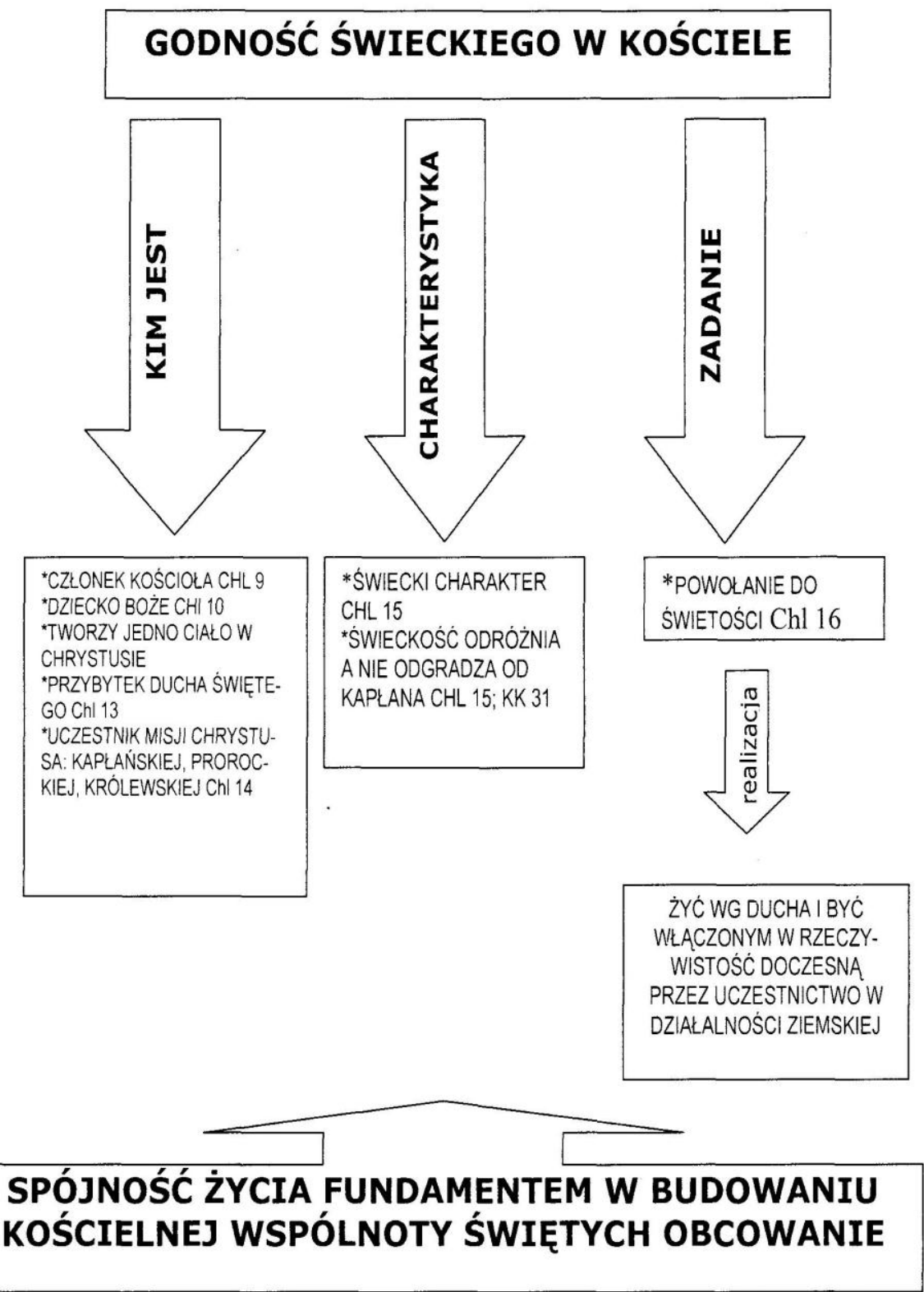




\section{ZAŁĄCZNIK 2:}

TEKST 1: Lud Boży należy do tego świata. Jest on związany ze światem jako miejscem swego pielgrzymowania i swojej próby. Syn Boży nie oderwał ludzkości od świata, ale tylko dopomógł zrozumieć do końca nasz związek z nim. (...). Związek ludzkości ze światem widzialnym jest prostą konsekwencją stworzenia. Syn Boży wchodzi w dzieło stworzenia i w nim rozbudowuje Mistyczne Ciało swego Kościoła. Zadania Ludu Bożego pozostają na płaszczyźnie dzieła stworzenia i idą dokładnie w parze z każdym etapem jego rozwoju. Jest to rozwój świata dokonywany przez człowieka i nosi na co dzień ludzkie znamiona.

Tym niemniej Syn Boży wszedłszy w ludzkość chce nade wszystko pracować przez Kościół nad przezwyciężeniem zła. Jest w organizacji Ludu Bożego głęboko ukryte prawo walki o człowieka, o jego wartość: naturalną i nadprzyrodzoną - jak to czynił sam Chrystus.

Przyzwyczailiśmy się w naszym języku posługiwać się słowem: świeccy. Świeccy, to znaczy związani ze światem. Z tymi wartościami, które się otwierają przed człowiekiem w świecie, z jego immanentną celowością, z której wyrastają dla człowieka różnorodne zadania. Zadania te mają na celu rozwój świata i rozwój człowieka w świecie.

Lud Boży - i to właśnie przede wszystkim świeccy - mają tutaj zadanie najbardziej bezpośrednie. Im został przede wszystkim powierzony świat. Aby wnieśli weń, we wszystkie dziedziny jego egzystencji to, co jest w Synu Bożym. - A co jest w Synu Bożym? - W Chrystusie jest nade wszystko: prawda i miłość. I to właśnie prawda i miłość w zetknięciu ze światem, rozłożona na tyle konkretnych spraw, uczynków, sytuacji, trudności. Prawda i miłość może być w świecie wyłącznym udziałem człowieka: emanacją jego ducha. Prawda i miłość jest koniecznym warunkiem spotykania się świata z Bogiem.

Jeśli mnie ktoś zapyta: jaka jest rola świeckich w Kościele, to odpowiem, że polega ona na stałym dopełnianiu dzieła Chrystusa - Syna Bożego w świecie i przy pomocy świata. Polega na stałym odzyskiwaniu świata we wszystkich dostępnych jego rejonach i przejawach, dla Ojca Przedwiecznego. Na drodze do tego celu leży jednak jeszcze wyższy: jest to mianowicie odzyskiwanie dla Ojca Przedwiecznego samego człowieka, w jego człowieczeństwie. Odzyskiwanie siebie i drugich, odzyskiwanie rodzin i wspólnot, środowisk, szczepów czy plemion, wsi i miast, narodów i państw. I odzyskiwanie dla tego Ojca - do którego zwracamy się w modlitwie z przydawką: „nasz” - tylu różnych form ludzkiej pracy, twórczości, miłości, badań i poszukiwań, rozrywki i odpoczynku wszystkiego wreszcie, co nosi na sobie znamię życia i działalności człowieka. 
Rola laikatu w Kościele ma swoją własną specyfikę. Na miarę współczesności, na miarę ludzkich możliwości. I powiedziałbym także: na miarę ludzkiej słabości.

To wszystko już wyraziło się w Ewangelii. Świeccy od swej strony tworzą Kościół. Tworzą - to znaczy są twórczy, twórczością całego swojego życia: pracy, radości, odpoczynku czy cierpienia. A źródłem tej twórczości jest Ewangelia gruntownie odczytana. I źródłem jest Łaska rozwijająca się w duszy na miarę własnego stanu powołania.

Rola świeckich w Kościele choć odrębna, jest jednak zespolona z rola duchownych. Zadanie bezpośrednie tych ostatnich stanowi słowo Ewangelii i środki Łaski przy pomocy których świeccy odzyskują świat dla Ojca. To ścisłe połączenie duchownych ze świeckimi w Kościele jest znamieniem charakterystycznym Ludu Bożego. U jego początku stoi Chrystus-Kapłan. Katolicy żyjący w świecie muszą dziś w ogromnej mierze odzyskać świadomość tego udziału, jaki im przypada w Kapłaństwie Chrystusa - to znaczy przemyśleć gruntownie fakt swojego chrztu i bierzmowania.

Wszystko to, aby nie pozbawić się poczucia wielkiego powołania i żeby dobrze spełnić rolę w Kościele ${ }^{21}$.

TEKST 2: Istotnym wymiarem powołania i misji chrześcijanina jest dawanie świadectwa o zbawczej obecności Boga w ludziach, jak to trafnie ujmuje temat kongresu: „Świadkowie Chrystusa w nowym tysiącleciu”. (...) Nikt nie może się uchylić od odpowiedzialności na pewne kluczowe pytania: Co uczyniłem z moim chrztem i bierzmowaniem? Czy Chrystus naprawdę stanowi centrum mojego życia? Czy w ciągu dnia znajduję czas na modlitwę? Czy postrzegam swoje życie jako powołanie i misję? Chrystus przypomina nam nieustannie: Wy jesteście solą ziemi (...). Powołanie i misję wiernych świeckich można zrozumieć jedynie w świetle odnowionej wizji Kościoła jako „sakramentu, czyli znaku i narzędzia wewnętrznego zjednoczenia z Bogiem i jedności całego rodzaju ludzkiego" oraz w świetle osobistej powinności głębszego związania się z nim. Kościół jest tajemnica Komunii, która ma swoje źródło w życiu Trójcy Świętej. Jest mistycznym Ciałem Chrystusa. Jest Ludem Bożym, który zespolony jedną wiarą, nadzieją i miłością pielgrzymuje przez dzieje ku nieprzemijającej ojczyźnie niebieskiej. My zaś, jako ochrzczeni, jesteśmy żywymi członkami tego wspaniałego i zachwycającego organizmu, karmiącego się darami sakramentalnymi, hierarchicznymi i charyzmatycznymi, które w nim współistnieją. Dlatego jest dziś

${ }^{21}$ K. W ojtyła: Lud Boży (z przemówienia w Radio Watykańskim 25.11.1963 r.) „Przewodnik Katolicki”. R. 1964 nr 7 s. 65 
szczególnie konieczne, aby chrześcijanie oświeceni i prowadzeni przez wiarę, poznawali prawdziwą tożsamość Kościoła, całe jego piękno i świętość, a dzięki temu mogli czuć razem z nim i kochać go jak własną matkę. Z myślą o tym należy rozbudzać prawdziwy sensus Ecclesiae, połączony z wewnętrzną świadomością bycia Kościołem, to znaczy tajemnicą komunii.

$\mathrm{Na}$ progu trzeciego tysiąclecia Bóg powołuje wierzących, a w szczególny sposób świeckich, do podjęcia z nową energią dzieła misyjnego. Misja nie jest jakimś dodatkiem do chrześcijańskiego powołania. Przeciwnie, jak przypomina Sobór Watykański II, powołanie chrześcijańskie jest ze swej natury powołaniem do apostolstwa. Chrystusa należy głosić świadectwem życia i słowem, ponieważ apostolat nie ma być tylko działaniem planowanym i zorganizowanym, ale przede wszystkim radosnym i pełnym wdzięczności dzieleniem się z wszystkimi darem spotkania z Chrystusem. Jednostka lub społeczność w sensie ewangelicznym odczuwa gorliwość misyjną, która przynagla do dawania świadectwa o Chrystusie w każdych okolicznościach i sytuacji, w każdym kontekście społecznym, kulturowym i politycznym. Drodzy bracia i siostry, Kościół potrzebuje was i liczy na was! Umacnianie i obrona godności i praw człowieka, dzisiaj szczególnie potrzebne, wymaga ludzi odważnych i kierujących się wiarą, zdolnych do bezinteresownej i współczującej miłości, szanujących prawdę o człowieku, stworzonym na obraz Boży i przeznaczonym do tego, aby dorastać „do miary według Pełni Chrystusa" (por. Ef 4,13) Nie zniechęcajcie się złożonością sytuacji! W modlitwie szukajcie źródła apostolskich energii; w Ewangelii szukajcie światła, które będzie wami kierować. Złożoność sytuacji nie powinna was zniechęcać, ale przeciwnie - skłaniać do mądrego i odważnego poszukiwania właściwych dróg działania, które pozwolą zaspokoić potrzebę chleba i pracy, wolności, pokoju i sprawiedliwości, wspólnoty i solidarności.

Drodzy wierni, jesteście powołani, aby podjąć ofiarnie spoczywającą na was część odpowiedzialności także za życie wspólnot kościelnych, do których należycie. Oblicze waszych parafii, które winny być wspólnotami otwartymi i misyjnymi, zależy od was. Żaden ochrzczony nie może trwać w bezczynności. Świeccy chrześcijanie, mający udział w misji kapłańskiej, prorockiej i królewskiej Chrystusa oraz wzbogaceni licznymi charyzmatami, mogą wnosić swój wkład w kształtowanie liturgii, w katechezę, w różnego rodzaju inicjatywy misyjne i charytatywne ${ }^{22}$.

\footnotetext{
${ }^{22}$ Por. J a n P a w e 1 I I: Jesteście świadkami Chrystusa $w$ nowym tysiacleciu. Przestanie Ojca Świętego do uczestników Światowego Kongresu Katolików Świeckich w Rzymie. „L'Osservatore Romano”. Wydanie polskie. R. 22: 2001 nr 2 (230) s. 39-41.
} 
ZALĄCZNIK 3:

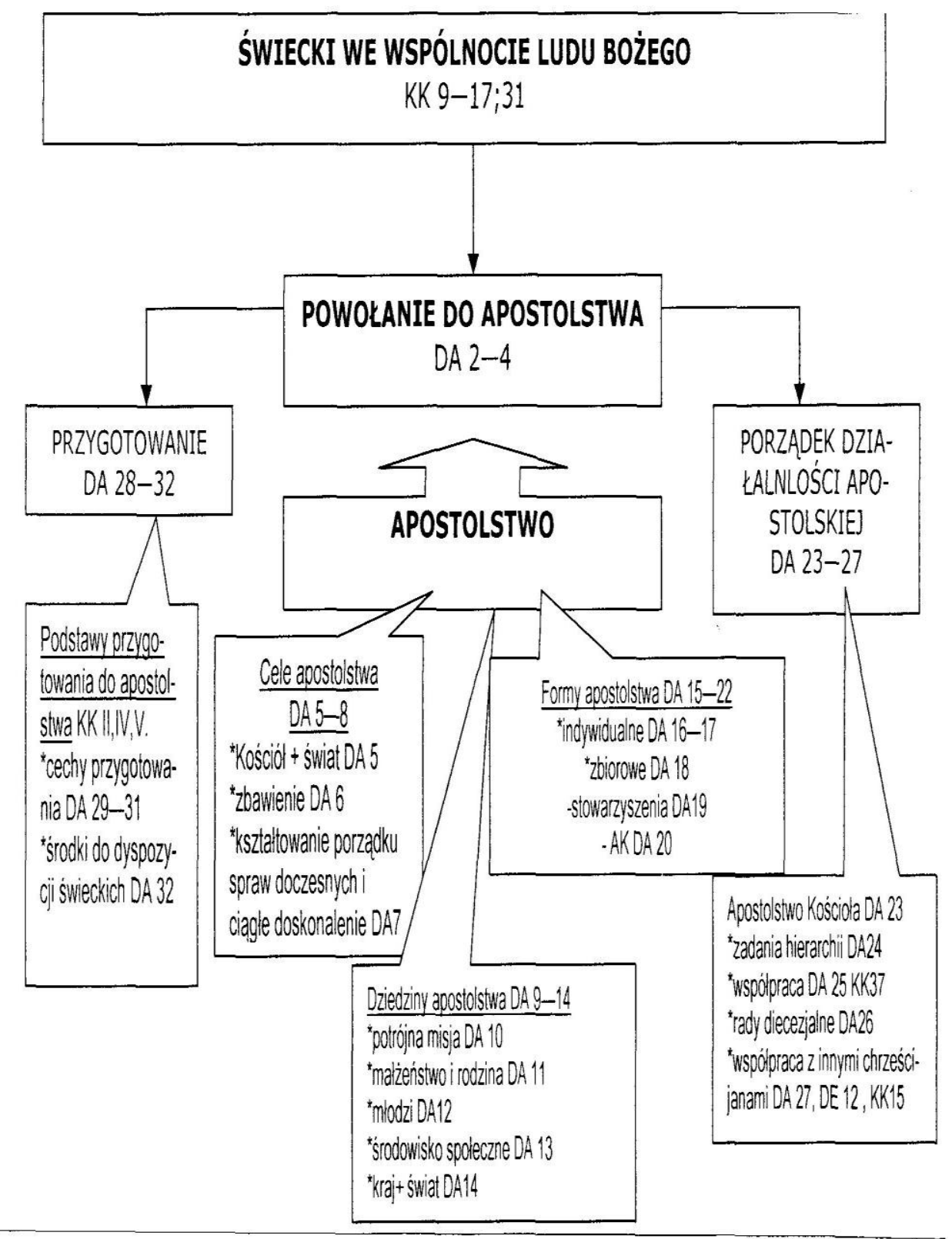


ZAŁĄCZNIK 4:

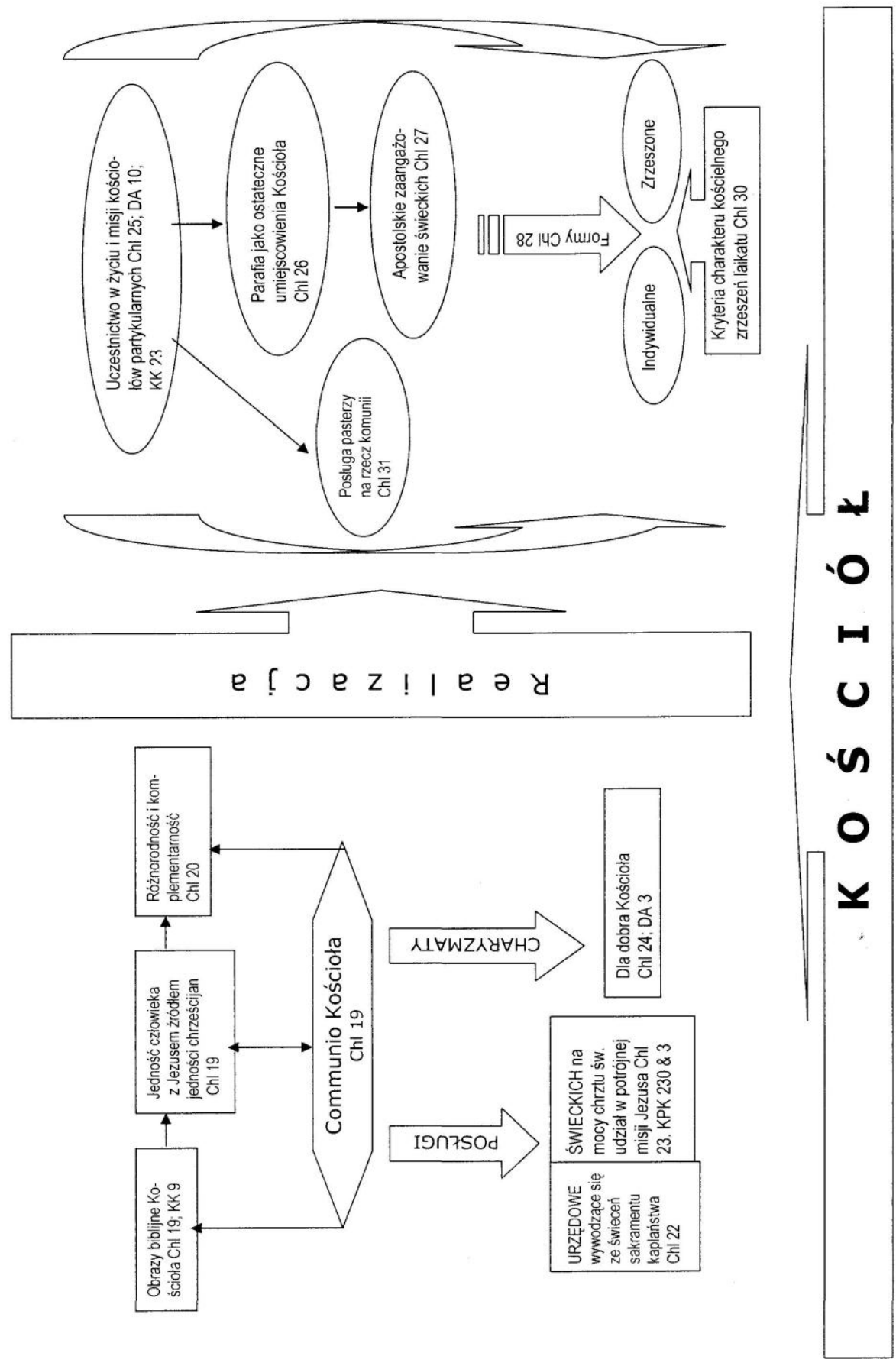

